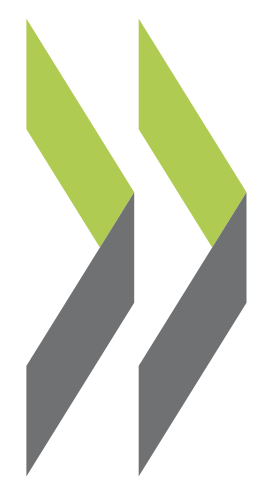

OECD Economics Department Working Papers No. 1059

\section{Banks' Restructuring}

and Smooth Deleveraging

of the Private Sector

in Slovenia

\title{
Olena Havrylchyk
}

https://dx.doi.org/10.1787/5k44v5122gf0-en 


\section{Unclassified}

ECO/WKP(2013)51

Organisation de Coopération et de Développement Économiques

Organisation for Economic Co-operation and Development

14-Jun-2013

ECONOMICS DEPARTMENT

English - Or. English

BANKS' RESTRUCTURING AND SMOOTH DELEVERAGING OF THE PRIVATE SECTOR IN SLOVENIA

ECONOMICS DEPARTMENT WORKING PAPERS No. 1059

By Olena Havrylchyk

All Economics Department Working Papers are available on the OECD's Internet website at http://www.oecd.org/eco/Workingpapers

JT03341891

Complete document available on OLIS in its original format

This document and any map included herein are without prejudice to the status of or sovereignty over any territory, to the delimitation of international frontiers and boundaries and to the name of any territory, city or area. 


\section{ABSTRACT/RÉSUMÉ \\ Banks' restructuring and smooth deleveraging of the private sector in Slovenia}

Slovenia is facing the legacy of a boom-bust cycle that has been compounded by weak corporate governance of state-owned banks. The levels of non-performing loans and capital adequacy ratios compare poorly in international perspective and may deteriorate further, which could require significant bank recapitalisation. Updated bottom-up (i.e. loan by loan) stress tests are needed to evaluate the extent of the problems, as the situation has deteriorated rapidly since a similar exercise was done for the two main stateowned banks in mid-2012. To foster the credibility of the new tests, the main results and underlying assumptions should be made public. The creation of the Bank Asset Management Company (BAMC) should allow recognition of problems by ring-fencing impaired assets, which would create conditions for an orderly resolution of non-viable banks and a rapid privatisation of viable banks. To that end, the process of asset transfer and their management has to be transparent and isolated from political influences by ensuring full independence of the BAMC. To achieve smooth deleveraging of the non-financial sector, viable but distressed enterprises should be restructured while insolvent firms should be swiftly liquidated. The main challenge is to improve inefficient insolvency procedures that are too long and result in low recovery rates. Development of equity markets can also facilitate smoother corporate deleveraging by facilitating equity raising through privatisation and entry of foreign investors. Finally, to prevent future crises, banking supervision should be enhanced further. This Working Paper relates to the 2013 OECD Economic Review of Slovenia (http://www.oecd.org/eco/surveys/slovenia-2013.htm).

JEL Classification: G21, G28, G33, G34.

Keywords: Slovenia, banks, financial regulation, insolvency, corporate governance.

$* * * * * * *$

\section{Restructuration des banques et désendettement en douceur du secteur privé en Slovénie}

La Slovénie est confrontée à l'héritage d'un cycle expansion-récession dont l'amplitude a été aggravée par la gouvernance médiocre des banques publiques. Les niveaux des prêts non performants et des ratios d'adéquation des fonds propres sont préoccupants dans une optique de comparaison internationale et risquent de se dégrader encore, ce qui obligerait à une recapitalisation importante des banques. Il faut actualiser les tests de résistance prêt par prêt pour évaluer l'étendue des difficultés, car la situation a rapidement empiré depuis la mi2012, date à laquelle on a effectué un exercice similaire pour les deux plus grandes banques publiques. Afin que les nouveaux tests soient crédibles, les principaux résultats et les principales hypothèses sous-jacentes devront être rendus publics. La mise en place d'une société de gestion des actifs bancaires (BAMC) devrait permettre de prendre la mesure des problèmes en isolant les actifs dépréciés, ce qui créerait les conditions d'une résolution ordonnée des établissements non viables et d'une rapide privatisation des établissements viables. À cette fin, le transfert des actifs et leur gestion doivent être transparents et tenus à l'écart des influences politiques au moyen de la pleine indépendance de la BAMC. Pour parvenir à un désendettement en douceur du secteur non financier, il conviendra de restructurer les entreprises viables, mais en difficulté, et de liquider promptement celles qui sont insolvables. Le principal défi à relever est l'amélioration des procédures de liquidation qui sont trop longues et qui aboutissent à de faibles taux de recouvrement des créances. Le développement du marché des actions peut aussi faciliter un désendettement en bon ordre des entreprises en favorisant l'augmentation des fonds propres par la privatisation et l'entrée d'investisseurs étrangers. Enfin, pour prévenir de nouvelles crises, il faut renforcer la supervision des banques. Ce Document de travail se rapporte à l'Étude économique de l'OCDE de la Slovénie 2013 (http://www.oecd.org/fr/eco/etudes/slovenie-2013.htm)

Classification JEL : G21, G28, G33, G34.

Mots clefs : Slovénie, banques, régulation financière, insolvabilité, gouvernance d'entreprise,

(C) OECD (2013)

You can copy, download or print OECD content for your own use, and you can include excerpts from OECD publications, databases and multimedia products in your own documents, presentations, blogs, websites and teaching materials, provided that suitable acknowledgment of $\mathrm{OECD}$ as source and copyright owner is given. All requests for commercial use and translation rights should be submitted to rights@oecd.org. 


\section{TABLE OF CONTENTS}

\section{BANKS' RESTRUCTURING AND SMOOTH DELEVERAGING OF THE PRIVATE SECTOR IN

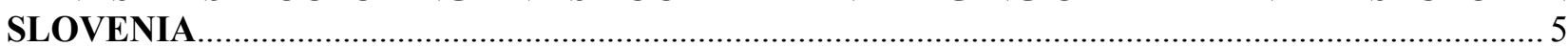

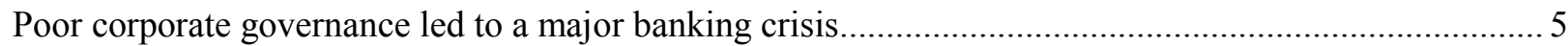

As many banks remain fragile, a comprehensive restructuring of the banking sector is needed .............. 14

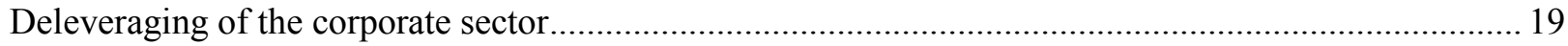

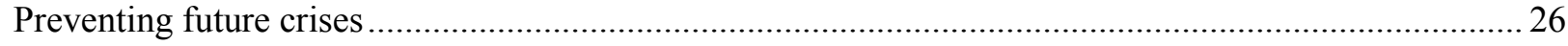

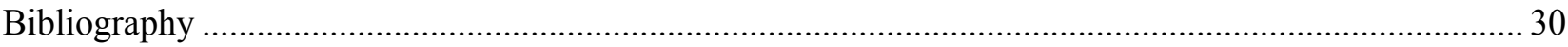

\section{Boxes}

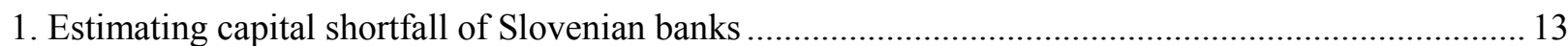

2. Bank Asset Management Company (BAMC) ................................................................................... 15

3. Recommendations to restructure banks and smooth deleveraging of the private sector.....................29

\section{Tables}

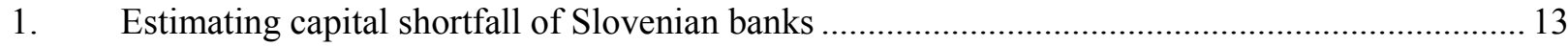

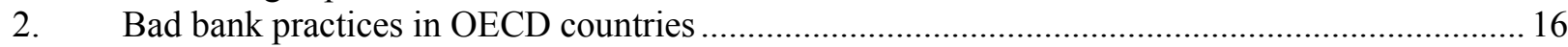

\section{Figures}

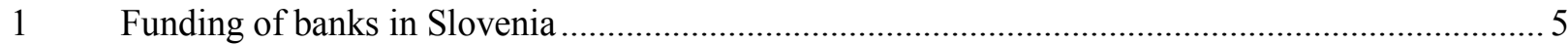

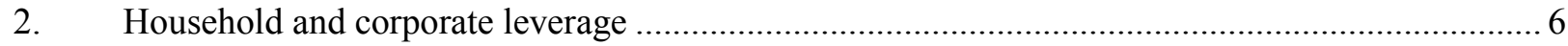

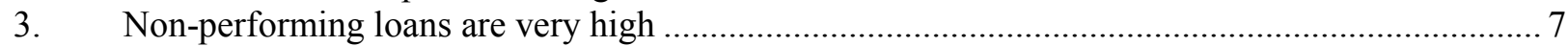

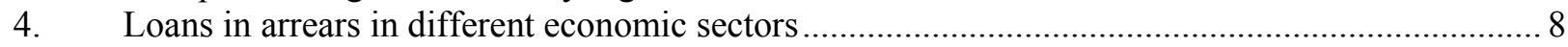

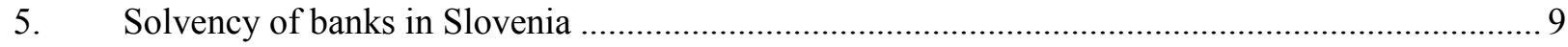

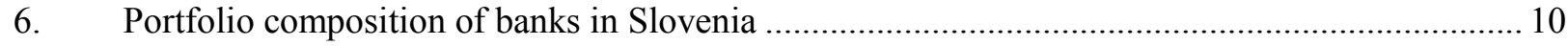

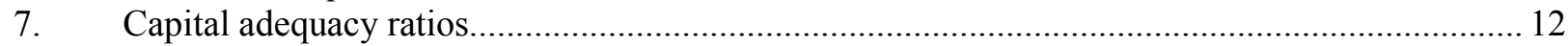

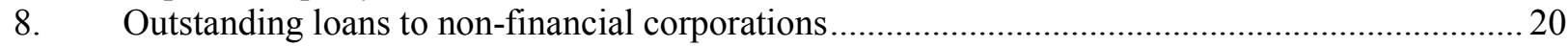

9. Development of foreign liabilities and liabilities from the Eurosystem .......................................20

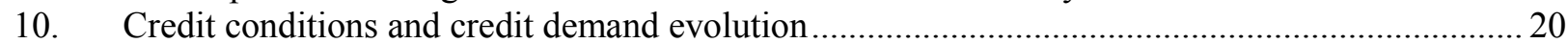

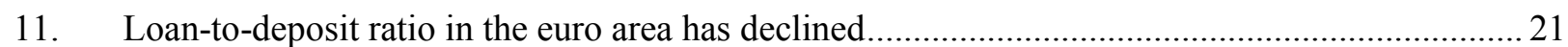

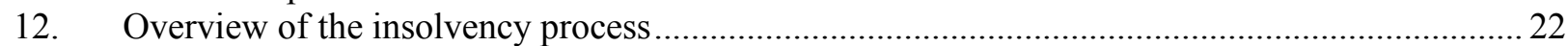

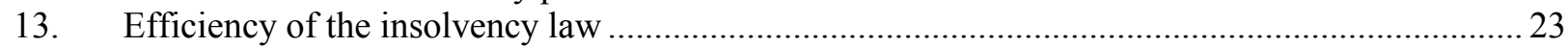

14. Public ownership is large and foreign direct investment is low ..............................................25 
ECO/WKP(2013)51 


\title{
Banks' restructuring and smooth deleveraging of the private sector in Slovenia
}

\author{
By \\ Olena Havrylchyk ${ }^{1}$
}

\section{Poor corporate governance led to a major banking crisis}

\section{A boom-bust credit cycle led to an over-indebted corporate sector and high impaired loans}

In the run up to the crisis, the loan-to-GDP ratio of Slovenian banks more than doubled from around $40 \%$ of gross domestic product (GDP) in 2003 to close to $90 \%$ in 2008 . This increase reflected a combination of low interest rates and a massive inflow of foreign funding, which reached more than $30 \%$ of banks' liabilities and boosted the loan-to-deposit ratio, which peaked at $160 \%$ in mid-2008. Not all banks were exposed in the same manner: in 2008 , the loan-to-deposit ratio was at $140 \%$ for large statecontrolled banks, $110 \%$ for small domestic banks and $260 \%$ for foreign banks (Figure 1, Panel A).

Figure 1. Funding of banks in Slovenia ${ }^{1}$

End of year ${ }^{2}$
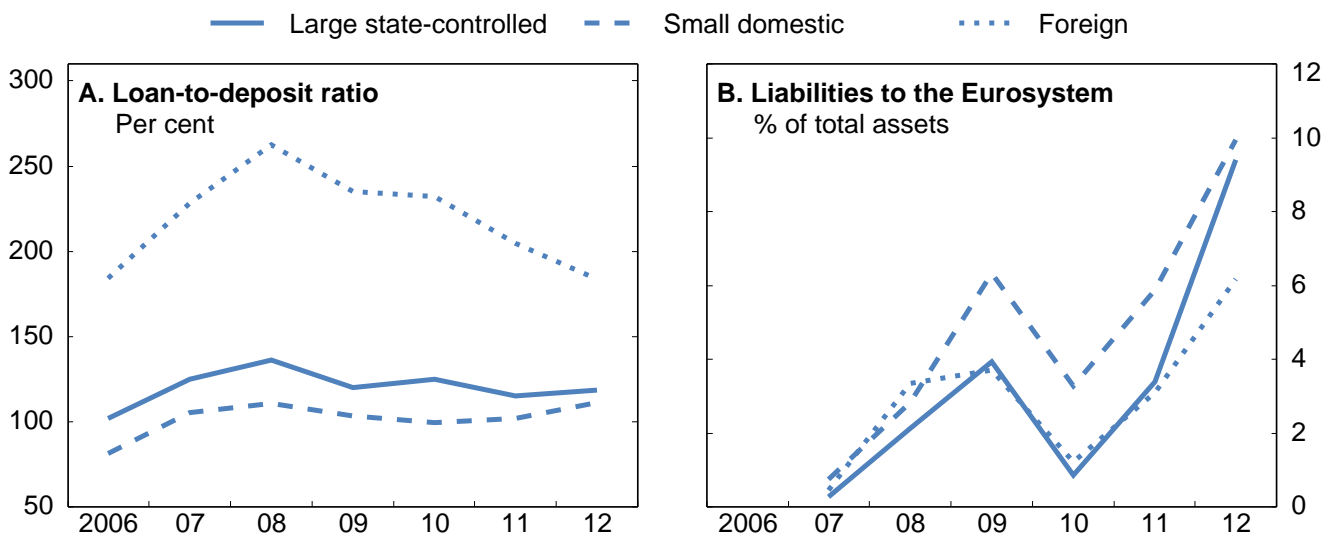

1. The category "large state-controlled" covers banks where the state holds, either directly or indirectly, a blocking minority shareholding. It covers the following: NLB, NKBM, Abanka, Banka Celje, SID banka and Gorenjska banka. Based on the latest data available, the share of each category of banks in terms of loans is $58 \%$ for large state-controlled, $8 \%$ for small domestic and $34 \%$ for foreign banks.

2. For 2012 the data provided is for October.

Source: Bank of Slovenia.

1 Economist at CEPII (olena.havrylchyk@cepii.fr). The paper was prepared when the author was external consultant to the OECD. This working paper was originally published as Chapter 1 of the 2013 OECD Economic Survey of Slovenia, published under the authority of the Economic and Development Review Committee (EDRC). The author is grateful to Pierre Beynet, Andrew Dean, Robert Ford and Rafal Kierzenkowski for helpful discussions, comments and suggestions, as well as Desney Erb for excellent statistical assistance. 
As the crisis has unveiled, the loan-to-deposit ratios have declined substantially to an average of $136 \%$ (October 2012) and currently only foreign banks exhibit high ratios (180\% in October 2012). By contrast, the loan-to-GDP ratio has kept increasing up to $92 \%$ in 2011 due to the collapse of GDP. Instead of cross-border loans, banks have resorted to funding from the Eurosystem (Figure 1, Panel B). In October 2012, the share of Eurosystem liabilities reached $8 \%$ of total assets due to the use of different unconventional instruments by the European Central Bank (ECB), such as fixed rate full allotment and long-term refinancing operations of different maturities.Fuelled by banking loans, the leverage of Slovenian non-financial corporations has increased. Although the current level of the debt-to-GDP ratio, at close to $141 \%$, is slightly above the OECD average, there are a number of risks that point to its unsustainability. The largest risk is related to the weak corporate governance of state-owned banks (SOBs), which is discussed below. Another risk is that the amount of equity is very low and, thus, leverage is high. The debt-to-equity ratio rose by around 60 percentage points between 2001 and 2008, one of the largest increases in the OECD, and it still stands at 143\% in 2011 (Figure 2, Panel A).

Figure 2. Household and corporate leverage ${ }^{1}$

Per cent

A. Debt-to-equity ratio of non-financial corporations ${ }^{2}$
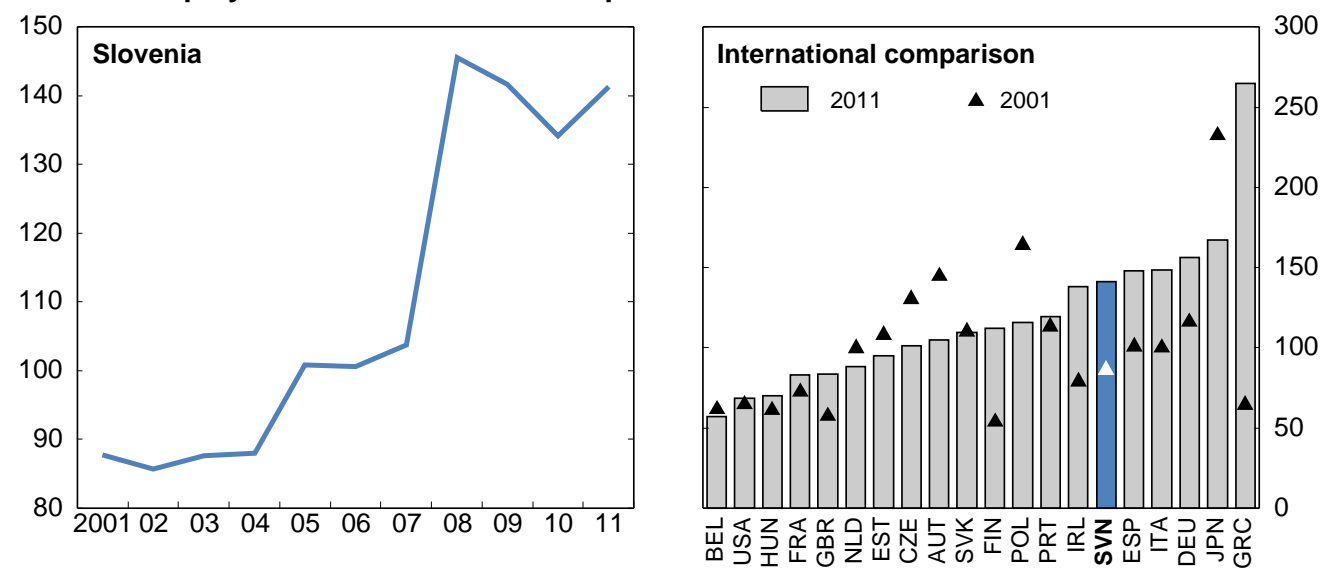

\section{B. Ratio of household debt to gross disposable income ${ }^{3}$}
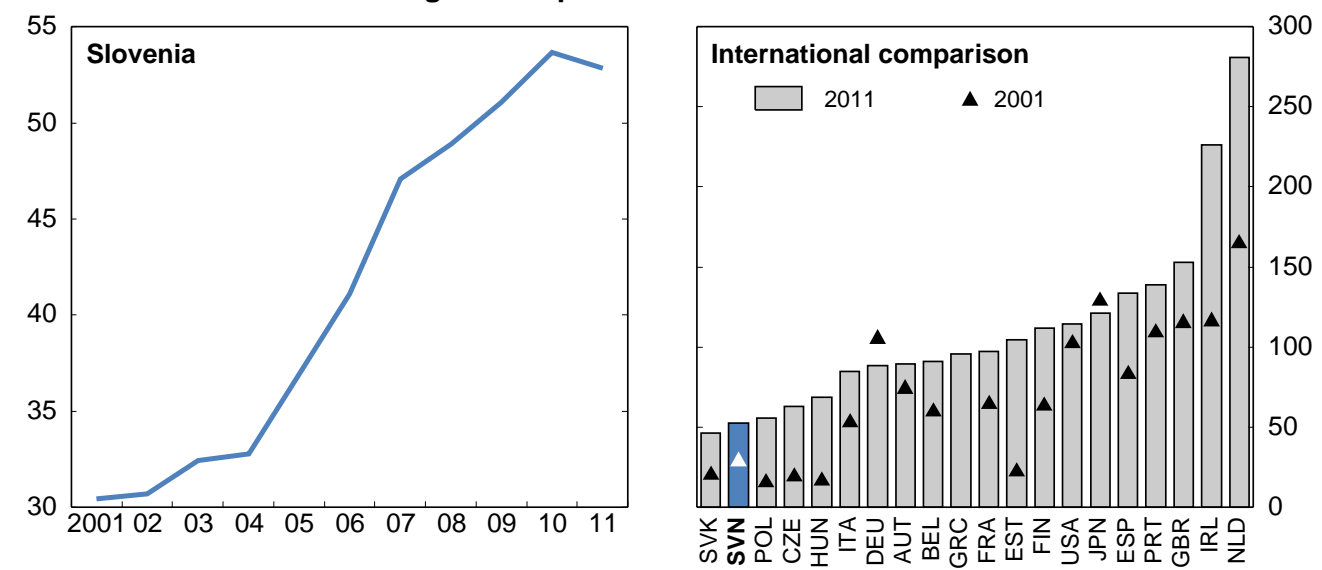

1. The debt used in the calculations is the sum of the following liability categories, whenever available/applicable: currency and deposits, securities other than shares (except financial derivatives), loans, insurance technical reserves and other accounts payable.

2. Debt as a percentage of shares and other equity. Data for 2010 instead of 2011 for Estonia and Japan.

3. Data for 2002 instead of 2001 for Ireland; 2010 instead of 2011 for Estonia, Japan and Poland.

Source: OECD (2013), "OECD Financial Dashboard”, OECD National Accounts Statistics (database), March. 
Construction and real estate sectors are the most indebted as their debt-to-equity ratios exceed $315 \%$. The high debt-to-equity ratios are in sharp contrast to other transition countries, such as Hungary or Estonia, where debt-to-equity ratios have remained stable despite the explosion of debt relative to GDP. The poor situation in Slovenia reflects substantial difficulties of companies in raising equity due to shallow local capital markets and limited foreign direct investment. In the medium term, the necessary deleveraging should be achieved not only by reducing the debt, but also by raising new equity.

By contrast, household indebtedness is low (Figure 2, Panel B). Despite house price overheating in some parts of the country, relatively prudent lending in general (loan-to-value ratios peaked at around $60 \%$ in 2007 and declined to $54 \%$ in 2012) has protected households from a major deterioration of their balance sheets. Nevertheless, a further deterioration of the labour market is likely to put pressure on repayment capabilities and there are a number of risks that can materialise in the future. Real estate prices fell by $12 \%$ between end 2007 and the third quarter of 2012, but many market participants expect them to decline further: the number of transactions dropped by $45 \%$ between the end of 2007 and the third quarter of 2012. Another risk is related to the $17 \%$ of housing loans that are denominated in Swiss francs (December 2012): the steep appreciation of the Swiss franc since 2008 has increased the repayment burden for these borrowers, but the ceiling on the exchange rate introduced by the Swiss Central Bank in September 2011 has prevented further deterioration.

The unwinding of the boom has led to a high proportion of non-performing loans (NPLs), defined as all classified claims to clients in arrears over 90 days. NPLs jumped to $14 \%$ of the credit portfolio (19\% of GDP) in October 2012, one of the highest ratios in the OECD (Figure 3). As the recession drags on, this is likely to deteriorate further. When considering all claims in arrears (i.e. even those that are in arrears by less than 90 days), they represent $21 \%$ of the credit portfolio or $28 \%$ of GDP. The situation is particularly worrying in the non-financial corporate sector where claims to clients in arrears for more than 90 days reached $24 \%$ in October 2012. Construction companies are responsible for a large share, as $62 \%$ of their claims are overdue for more than 90 days and the largest companies are insolvent (Figure 4). NPLs are also high $(36 \%$ of the credit portfolio) in the financial intermediation sector that mostly includes financial holding companies that were used for privatisation through leveraged buy-outs. In contrast, the share of clams in arrears for households is much smaller, at $4 \%$ of total household loans.

Figure 3. Non-performing loans are very high ${ }^{1}$

Non-performing loans in per cent of total gross loans, $2012^{2}$

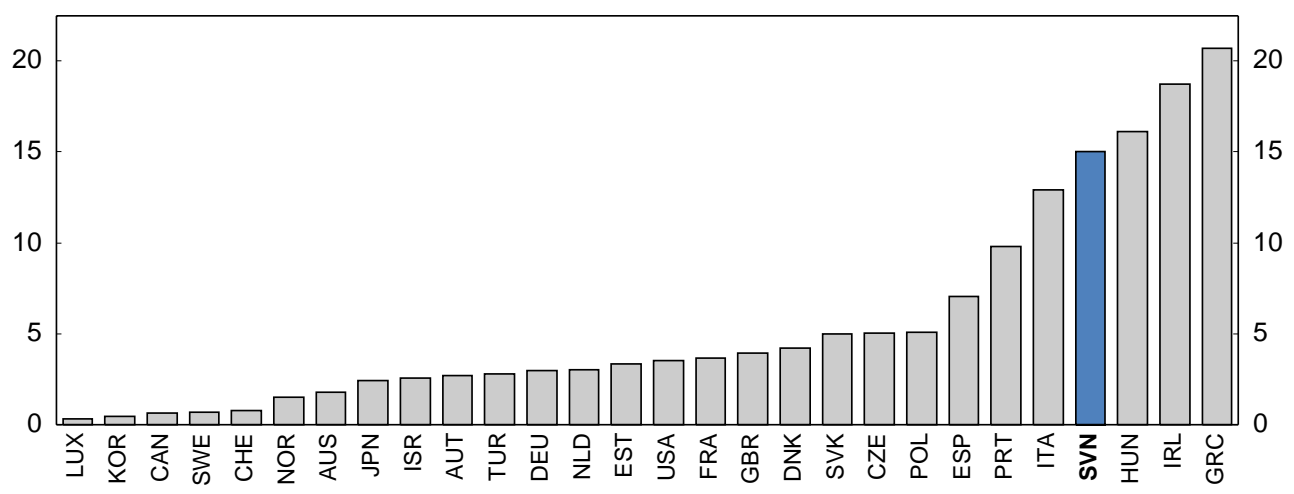

1. Overdue or non-performing loans are loans (claims in the case of Slovenia) with failed payment obligations for at least 90 days.

2. Latest quarter based on available bank balance sheet data; third quarter of 2012 for the majority of countries shown.

Source: IMF (2013), Financial Soundness Indicators, International Monetary Fund, March, http://fsi.imf.org. 
Figure 4. Loans in arrears in different economic sectors

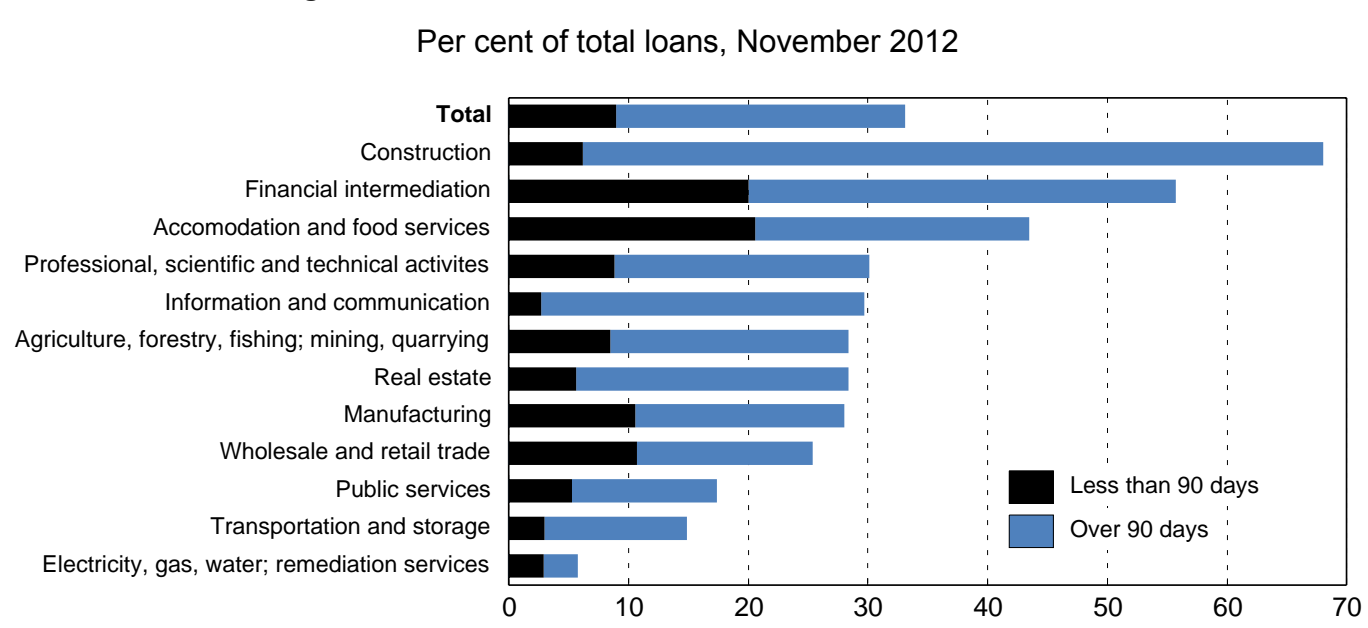

Source: Bank of Slovenia (2013), "Poslovanje bank v tekočem letu, gibanja na kapitalskem trgu in obrestne mere", February.

The high level of NPLs is explained by the fact that banks accumulate bad loans and do not write them off, even when the necessary provisions are accumulated. The average monthly ratio of written-off loans to overdue loans was only $0.2 \%$ in the first nine months of 2012 , and at that rate banks would require 38 years to clean up their loan portfolios. This compares poorly with other countries in the region, like Hungary and Estonia, which would require 6-7 years to completely clean their portfolios, which is already considered too long by their supervisors. Banks were unwilling to write-off their bad loans because of tax impediments, as they were uncertain if the write-offs were accounted as losses. The situation appears to be changing, as the tax authorities, at the request of the Bank of Slovenia, made it clear how the tax legislation should be implemented and thus confirmed that write-offs of bad loans can be treated as losses that decrease profits and, thus, taxes. This should affect claims classified as loss and that are fully provisioned, currently at $7 \%$ of total NPLs. Indeed, banks accelerated the cleaning up of their portfolios at the end of 2012 .

\section{Bank governance has a large impact on loan portfolio quality}

The bust has not affected all banks equally. The quality of the loan portfolio has deteriorated the most for large state-controlled banks that include both SOBs (i.e. banks where 50\% plus one share of equity is owned by the state) and other banks controlled by the state via smaller equity stakes. For these banks, the ratio of NPLs to private corporations increased from $2 \%$ in 2007 to $30 \%$ in October 2012 (Figure 5). In comparison, the corresponding ratio for foreign banks amounted to $11 \%$ and for small domestic banks to $23 \%$. This suggests that the increase in bad loans of state-controlled banks is not driven just by the business cycle. One explanation could be a wrong business model that relied on lending that was highly concentrated in the construction sector and financial holding companies. Conversely, the business model of foreign banks has been more concentrated on lending to households (Figure 6), who have had a lower default rate so far. 
Figure 5. Solvency of banks in Slovenia ${ }^{1}$

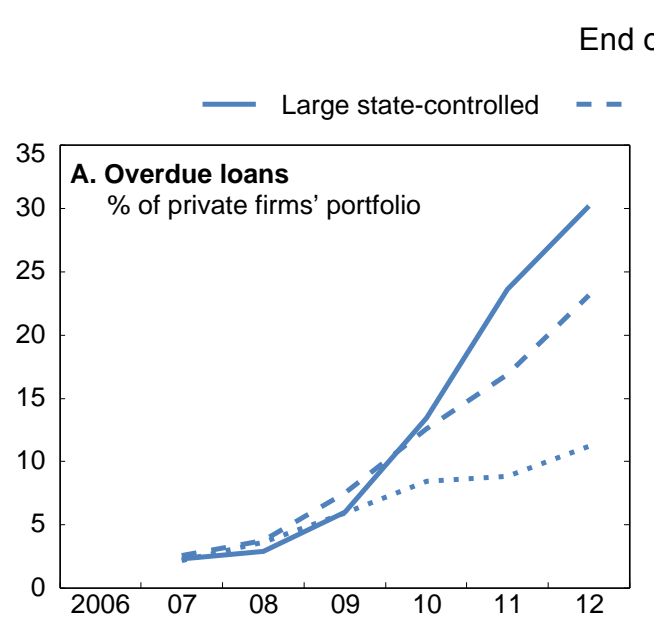

Small domestic

$\because$ Foreign

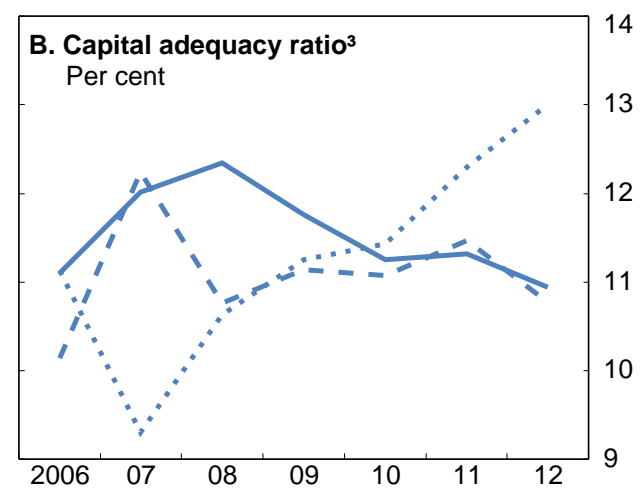

1. The category "large state-controlled" covers banks where the state holds, either directly or indirectly, a blocking minority shareholding. It covers the following: NLB, NKBM, Abanka, Banka Celje, SID banka and Gorenjska banka. Based on the latest data available, the share of each category of banks in terms of loans is $58 \%$ for large state-controlled, $8 \%$ for small domestic and $34 \%$ for foreign banks.

2. For 2012 the data provided is for October in Panel A and September in Panel B.

3. Total regulatory capital (Tier 1 plus Tier 2) as a per cent of risk-weighted assets.

Source: Bank of Slovenia.

Another explanation of the higher rates of arrears of SOBs could be corporate governance problems. Academic literature documents the fact that SOBs in many countries tend to provide credit to politically connected firms (Sapienza, 2004; Khwaja and Mian, 2005). Given high rates of arrears of SOBs and the poor institutional environment, one could suspect that credit misallocation has also taken place in Slovenia. Indeed, there is a perception of favouritism in decisions of government officials and government spending is considered to be somehow wasteful: according to the 2012/13 Global Competitiveness Report (WEF, 2012), Slovenia is ranked 104 and 118, respectively, placing it behind China and India. When recruiting public employees (that includes managers of SOBs), political connections often matter more than merit and skills: according to the Quality of Governance survey, only Italy and Mexico fare worse among OECD countries (Dahlström et al., 2011). In the context of an extensive public ownership (state-owned assets stand at around $11 \%$ of GDP in terms of corporate valuation), notably in the banking sector (state-owned banks account for $38 \%$ of total banking loans), governance of state-owned enterprises (SOEs) appears to be weak in Slovenia (OECD, 2011a). 
Figure 6. Portfolio composition of banks in Slovenia ${ }^{1}$

Per cent of total loan portfolio, end of year ${ }^{2}$

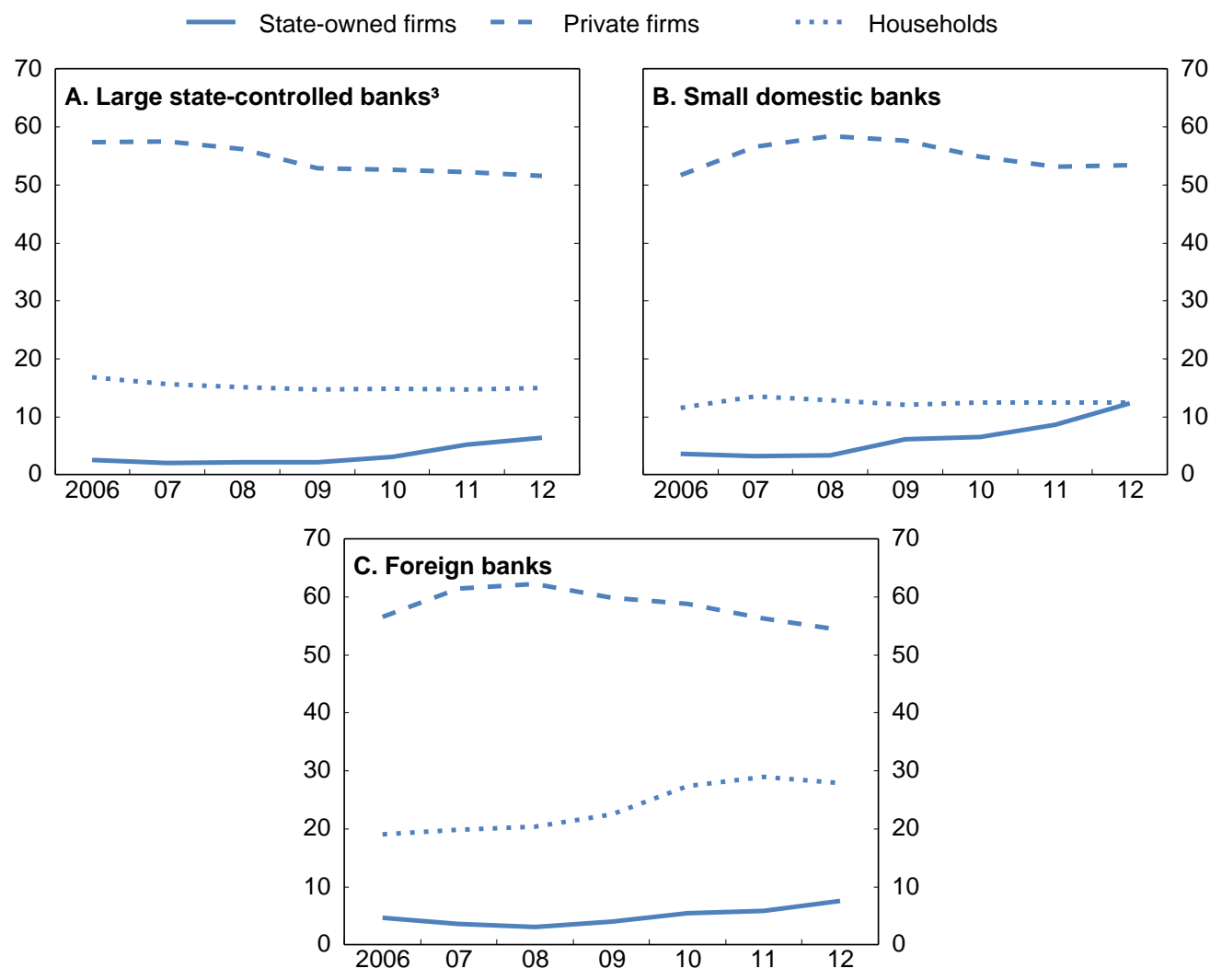

1. Based on the latest data available, the share of each category of banks in terms of loans is $58 \%$ for large state-controlled, $8 \%$ for small domestic and $34 \%$ for foreign banks.

2. Loan portfolio is defined as total classified claims. For 2012 the data provided is for October.

3. Banks where the state holds, either directly or indirectly, a blocking minority shareholding: NLB, NKBM, Abanka, Banka Celje, SID banka and Gorenjska banka.

Source: Bank of Slovenia.

Anecdotal evidence suggests that the management of the SOBs has at times pursued other objectives than business ones, often under political pressure. In 2009, the chief executive officer of the Nova Ljubljanska Banka (NLB), the largest Slovenian bank, resigned after three months in office citing political interference. In 2010, his successor resigned after one year in office feeling political pressure not to sell the bank's share in Mercator (a supermarket chain), considered by the state as a company of national strategic interest. The Nova Kreditna Banka Maribor (NKBM), the second largest bank, is suspected of having extended loans to shell companies that have cost the bank EUR 60 million. Loans at excessively favourable conditions to financial holding companies have underpinned unsustainable mergers and acquisitions, management buy-outs or buy-outs of public shares at high market values (Damijan, 2012). The media report cases where loans were granted to related parties at favourable conditions. The two largest SOBs NLB and NKBM - extended loans, amounting to, respectively, $20 \%$ and $15 \%$ of their capital, to the Zvon Ena financial holding company which is currently under bankruptcy procedures, and have also been heavily exposed to construction companies working on major public projects. Preliminary findings of the Slovenian Corruption Prevention Commission have recently pointed to widespread credit misallocation, likely related to corrupt behaviour. 
Given weaknesses in corporate governance, there is uncertainty about the banks' judgment on the quality of loans, as well as fears that banks may try to evergreen bad loans (roll them over to avoid recognising losses on their books) in order to mask losses. Also, given low recovery rates after insolvency procedures, banks are dissuaded from extricating themselves from lending to financially distressed businesses and instead are extremely cautious when extending new loans (European Commission, 2012). Renegotiated loans amount to $150 \%$ of total loans in arrears over 90 days, which could signal forbearance that makes balance sheets look stronger because banks do not need to put aside provisions, but it can erode faith in the strength of bank assets. If loans are renewed or renegotiated when the indebted company is distressed, the losses might increase in the future because the underlying asset will decline in value if not properly managed. This is likely to happen when renegotiation allows for only the extension of deadline or repayment postponement and does not include partial debt forgiveness, which is frequently necessary to return the distressed but viable company to a healthy state. As discussed earlier, the amount of written off loans is negligible in Slovenia. The quality of renegotiated loans is not known, as the Bank of Slovenia does not collect data on the share of renegotiated loans that used to be overdue and the share of renegotiated loans that become overdue afterwards.

There is evidence of crowding out of private credit by credit to SOEs: irrespective of the bank ownership, the share of credit to SOEs rose from 3\% to 7\% between 2008 and 2012 (Figure 6). It is difficult to evaluate the riskiness of these loans as the Bank of Slovenia does not publish or provide the share of overdue loans to SOEs. There is no evidence of increasing financial repression, but domestic banks (SOBs and private) allocate larger shares of their portfolios in government bonds than foreign institutions, which could, in the current juncture, trigger a negative feedback loop between government and banks: as the perception of public fiscal sustainability by financial markets is weak, higher spreads on government bonds would lead to further deteriorating bank balance sheets, which would in return increase the potential fiscal costs of a bail-out of public banks. All banks appear to have significantly curtailed their lending to private firms (the share has dropped by more than 6 percentage points). In comparison, the share of households in portfolios of foreign banks has increased from $20 \%$ in 2008 to $28 \%$ in 2012, reflecting the relative health of foreign banks and their interest in the household sector (Figure 6).

\section{Bank solvency is under severe pressure}

High credit risk has increased the need for provisioning, putting pressure on the profitability of Slovenian banks that has been negative since 2010. In October 2012, the loss coverage ratio, i.e. the ratio of loan loss reserves to loans in arrears over 90 days, stood at $57 \%$. However, it is important to note that between 2009 and the first half of 2011, banks were late to classify loans in higher provisioning categories even if they registered arrears, but the gap has been closing more recently. The provisioning is done in accordance with International Accounting Standards, in other words, on the incurred losses basis: this coverage ratio does not take into account expected losses on performing or restructured loans. Moreover, banks apply different provisioning methods that are not always comparable. For these reasons, the coverage ratio seems insufficient, especially since the amount of NPLs is very high in Slovenia. In order to ensure that adequate coverage exists when these loans migrate to the doubtful category, provisions should be set aside also for performing and restructured loans, as was done in Spain in May 2012, when provisioning rates on performing real estate developer loans were increased from $7 \%$ to $30 \%$.

Despite deleveraging and several injections of public funds into SOBs, Slovenian banks remain under-capitalised relative to those in other OECD countries (Figure 7). The large state-controlled banks report a capital adequacy ratio of $11 \%$ and a Tier 1 capital ratio of $10 \%$ as of October 2012 . The largest Slovenian bank, NLB, was recapitalised twice in 2011 and 2012 to the amount of EUR 624 million (1.7\% of GDP). The bank had announced that it would seek another recapitalisation of EUR 375 million in late 2012, but this plan was not approved by its shareholders and the Ministry of Finance argued that recapitalisation was not yet needed. At the end of December, $\mathrm{KBC}$, the largest foreign (Belgian) shareholder, sold its $22 \%$ share in NLB to the Slovenian state for EUR 2.76 million. Following 
recommendations of the European Banking Authority, the second largest bank, the Nova KBM, was supposed to increase its capital till September 2012, and this was achieved at the end of December 2012 via the sale of its insurance subsidiary, the redemption/exchange of hybrid notes and sale of CoCo bonds (contingent convertible securities) to the state. So far, total recapitalisation by the state has reached $2.5 \%$ of GDP, but growing loan loss provisions erode potential increases in capital. The Tier 1 capital ratio of small domestic banks is below 9\%. In contrast, foreign owners have recapitalised their Slovenian subsidiaries so that the total capital adequacy ratio of foreign banks has increased from $9.3 \%$ in 2007 to $13 \%$ in 2012 (Figure 5).

\section{Figure 7. Capital adequacy ratios}

Total regulatory capital as a per cent of risk-weighted assets, $2012^{1}$

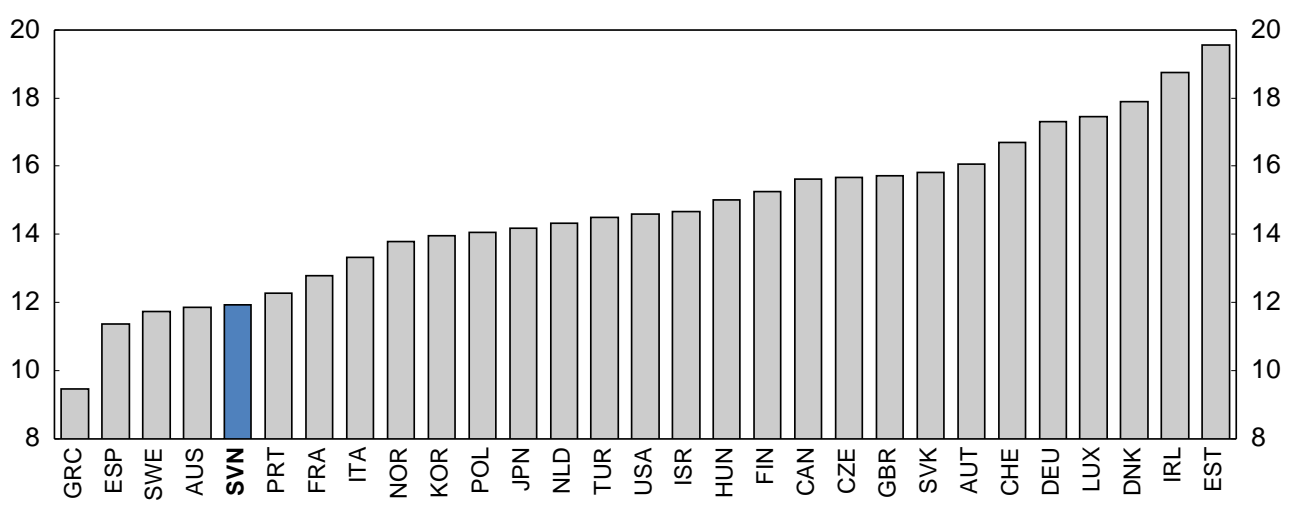

1. Latest quarter based on available bank balance sheet data; third quarter of 2012 for the majority of countries shown.

Source: IMF (2013), Financial Soundness Indicators, International Monetary Fund, March, http://fsi.imf.org.

Capital adequacy ratios of Slovenian banks are likely to decline once bad loans are recognised and some of them are written off. The authorities evaluate additional recapitalisation needs at 3\% of GDP. Yet, effective capital needs are uncertain and could in fact be significantly higher. While the central bank has performed stress tests (a top-down exercise based on macroeconomic scenarios) and a single consultancy firm, European Resolution Capital (ERC), has performed a due-diligence analysis of major banks (a bottom-up exercise with a loan-by-loan analysis), the main results have never been made public. This is in contrast to the practice in other countries facing severe banking difficulties, including the United States and Spain. While the due-diligence exercise was not officially made public, some experts argue that, six months after the exercise, its results are already outdated even under the stress scenario as the underlying assumptions were not sufficiently conservative and forward looking. Also, unofficial press reports suggest that the NLB suffered losses from Zvon Ena that are double of those estimated in the due-diligence report. Finally, it is not clear whether the assessment of the ERC and the Bank of Slovenia converge. According to the Slovenian Press Agency, some government officials claimed in mid-July 2012 that the due-diligence report and a report by the central bank show significantly different pictures.

To give an idea of the extent of potential recapitalisation needs, the OECD has done an illustrative estimation with two scenarios, based on data provided by the Bank of Slovenia. The idea is to identify potential capital shortage once estimated losses (which are a function of NPLs without taking into account collateral) are written off (see Box 1 for more details of the analysis). Results indicate that Tier 1 capital ratios of large state-controlled and small domestic banks have a high risk of becoming negative, whereas the ratio of foreign banks falls to $8-9 \%$. The potential amount of recapitalisation could reach about $5 \%$ of GDP. These scenarios do not take into account collateral, which offers relatively poor protection in Slovenia as it mainly consists of real estate which is a non-liquid asset and subject to major valuation uncertainties (IMF, 2012a). However, assuming that banks can realise at once $10 \%$ of its value (EUR 6.4 
billion) for claims in arrears over 90 days, then the potential capital shortfall could reach $3.2 \%$ of GDP. Conversely, capital requirements could be higher as the estimate does not take into account loans renegotiated before they became overdue or the use of more conservative risk-weights applied to assets, which could lead to additional losses. Overall, even though these scenarios are mainly illustrative, they reveal the extent of the problem for domestic banks, particularly the largest SOBs, while foreign banks appear to be in a better shape. It should be noted, however, that the proportion of loans in arrears of less than 90 days is higher for foreign banks than for domestic banks, which could indicate some further difficulties down the road for foreign banks also.

\section{Box 1. Estimating capital shortfall of Slovenian banks}

Table 1 provides an OECD estimation of potential capital shortfall for the Slovenian banking sector as a whole and separately for large state-controlled, small domestic and foreign banks. To do so, the capital shortfall (in value) is calculated as core capital needed after the write-off of expected losses to reach a Tier 1 capital ratio of $9 \%$. The following formula is used (with data in EUR):

$$
\text { Capital shortfall }=9 \% \text { * }(R W A-E L)-(\text { Tier } 1+L L R-E L)
$$

where RWA represents "risk weighted assets", Tier 1 the amount of "core capital", LLR the total of "loan loss reserves" and $E L$ the OECD simulation of losses using different hypotheses (see below). To compute EL, two scenarios are constructed using different sets of assumptions. The first scenario is the most simple: it assumes that all loans in arrears over 90 days not covered by reserves need to be fully written off while no losses are assumed for loans in arrears of less than 90 days. The second scenario is a bit more sophisticated and assumes different probability of losses depending on the duration of arrears: $20 \%$ loss rate is assumed for claims that are in arrears for less than 30 days; $30 \%$ for loans that are in arrears between 30 and 90 days; $70 \%$ for those between 90 days and one year and $100 \%$ for claims that are in arrears for more than one year. Such assumptions of loss rates are based on OECD (2012). ${ }^{*}$ Interestingly, both scenarios provide quite similar results, at least at the aggregated level.

Table 1. Estimating the capital shortfall of Slovenian banks

September 2012

\begin{tabular}{|c|c|c|c|c|}
\hline & All banks & $\begin{array}{l}\text { Large } \\
\text { state- } \\
\text { controlled } \\
\text { banks }\end{array}$ & $\begin{array}{c}\text { Small } \\
\text { domestic } \\
\text { banks }\end{array}$ & $\begin{array}{c}\text { Foreign } \\
\text { banks }\end{array}$ \\
\hline \multicolumn{5}{|l|}{ Current situation } \\
\hline Total Claims (billion EUR) & 49 & 30 & 4 & 15 \\
\hline \multicolumn{5}{|l|}{ Claims in arrears ( $\%$ of total claims) } \\
\hline Below 30 days & 4.1 & 3.7 & 2.2 & 5.4 \\
\hline Between 30 and 90 days & 1.8 & 1.9 & 1.7 & 1.7 \\
\hline Between 90 days and 1 year & 4.8 & 5.5 & 7.2 & 2.4 \\
\hline Over 1 year & 9.5 & 12.4 & 7.7 & 4.1 \\
\hline Tier 1 capital ratio ( $\%$ of risk weighted assets, RWA) & 10.2 & 9.8 & 8.6 & 11.4 \\
\hline \multicolumn{5}{|l|}{ First scenario: $100 \%$ losses for loans in arrears over 90 days } \\
\hline Estimated losses (billion EUR) & 7.0 & 5.3 & 0.7 & 1.0 \\
\hline Loss coverage ratio (loan loss reserves/estimated losses, \%) & 55.4 & 55.0 & 45.1 & 65.3 \\
\hline Resulting Tier 1 capital ratio after losses are written off ( $\%$ of RWA) & 1.8 & -1.5 & -2.3 & 9.0 \\
\hline Resulting capital shortfall (billion EUR) & 1.9 & 1.8 & 0.3 & -0.1 \\
\hline Resulting capital shortfall (\% of GDP) & 5.4 & 5.1 & 1.0 & -0.3 \\
\hline \multicolumn{5}{|l|}{ Second scenario: loss rate function of the duration of arrears } \\
\hline Estimated losses (billion EUR) & 6.9 & 5.2 & 0.6 & 1.1 \\
\hline Loss coverage ratio (loan loss reserves/arrears over 90 days, \%) & 55.7 & 56.0 & 49.3 & 57.6 \\
\hline Resulting Tier 1 capital ratio after losses are written off ( $\%$ of RWA) & 1.9 & -0.9 & -0.3 & 7.7 \\
\hline Resulting capital shortfall (billion EUR) & 1.9 & 1.7 & 0.3 & 0.0 \\
\hline Resulting capital shortfall (\% of GDP) & 5.3 & 4.7 & 0.8 & 0.1 \\
\hline
\end{tabular}

1. The category "large state-controlled" covers banks where the state holds, either directly or indirectly, a blocking minority shareholding. It covers the following: NLB, NKBM, Abanka, Banka Celje, SID banka and Gorenjska banka. Based on the latest data available, the share of each category of banks in terms of loans is $58 \%$ for large state-controlled, $8 \%$ for small domestic and $34 \%$ for foreign banks.

Source: OECD calculations based on Bank of Slovenia data. 
A few caveats should be applied to this analysis. Capital shortage could be lower as the estimate does not take into account collateral that could diminish losses, as collateral offers relatively poor protection in Slovenia as it mainly consists of real estate which is a non-liquid asset and subject to major valuation uncertainties (IMF, 2012b). Conversely, capital requirements could be higher as the estimate does not take into account loans renegotiated before they became overdue, but which could be subject to additional losses. More generally, the capital adequacy depends crucially on the risk-weights applied to assets. According to IMF (2012a), employment of enhanced capital measurement techniques, such as the Basel II internal rating based approach to credit risk, would increase capital requirements and would result in additional capital shortfalls.

* References: OECD (2012), OECD Economic Surveys: Hungary 2012 and IMF (2012b), "Republic of Slovenia: Detailed Assessment of Observance of Basel Core Principles for Effective Banking Supervision”, IMF Country Report, No. 12/324, International Monetary Fund.

Looking at market valuation gives a similar perception of potentially weak capitalisation of some banks. As of 26 December 2012, the price-to-book ratios on the Ljubljana Stock Exchange of NKBM and Abanka, the second and the third largest banks, stood at 0.12 and 0.13 (i.e. markets valued the equity of these banks at $12 \%$ and $13 \%$ of their book value). Even though price-to-book ratios have declined in all countries, the average ratios stand at 1.7 in Latin America, 1.4 in eastern Europe and 0.8 in developed markets (McKinsey, 2012). The shares of NLB are not traded on the stock exchange, but at the end of December 2012, the government bought a $22 \%$ share from the Belgian KBC for $1 \%$ of its book value. These low market valuations of bank equity are consistent with the OECD estimate in Box 1 of the Tier 1 capital ratios after the write-off of estimated losses.

\section{As many banks remain fragile, a comprehensive restructuring of the banking sector is needed}

Given the problem of high NPLs and the banks' inability to deal with them, the Bank Asset Management Company (BAMC), created in October 2012, could be seen as one element of the banks' restructuring and resolution framework (Box 2). The aim is to take over non-performing assets in return for government-guaranteed bonds of up to EUR 4 billion (11\% of GDP) and recapitalise participating banks at up to $3 \%$ of GDP (EUR 1 billion). Yet, the creation of the BAMC should be part of a more comprehensive restructuring of the banking sector. According to best practice, resolution procedures should involve independent due-diligence of the whole banking sector to divide banks into four groups: $i$ ) solvent institutions; $i$ i) viable banks that are currently distressed but can solve their problems without intervention; iii) viable banks that are currently distressed and require intervention; and $i v$ ) non-viable banks that need to be closed in an orderly way. Such classification of banks was used in Spain and Sweden, and is supported by the Bank of Slovenia. The current legislation on the BAMC does not rely on such classification and it is not clear which banks will participate in the transfer of assets. 


\section{Box 2. Bank Asset Management Company (BAMC) \\ Druzbo za upravljanje terjatev bank (DUTB)}

The law establishing the BAMC was passed on 23 October 2012. The objective of the BAMC is to enhance the stability of the Slovenian banking sector by purchasing non-performing assets and recapitalising banks. The law also states that the BAMC has the mandate to establish responsibility for the emergence of impaired loans and investments.

The description of risky assets that can be transferred will be determined by a government executive act and the price of transferred claims should reflect their real long-term economic value. The BAMC will be obliged to sell at least $10 \%$ of the estimated value of the assets each year and will be wound down after five years. The assets of the BAMC may be used to increase the equity capital of banks.

The BAMC will be financed with bonds, loans or other financial instruments which are guaranteed by the state and their issuance will take into account the conditions of the European Central Bank for financing financial institutions. The total scope of guarantees should not exceed the established ceiling of EUR 4 billion (11\% of GDP).

The BAMC management board shall have seven members of which three will be executive directors selected on the basis of a public call for applications and should comply with professional requirements (personal integrity, university degree, expertise in finance, banking corporate law and is not a bank shareholder), whereas non-executive directors shall be proposed by the Ministry of Economy. Their remuneration will be decided by the Assembly and not be constrained by the rules governing remuneration of public employees. Supervision of the BAMC shall be performed by the Ministry of Finance.

The initiative for the application may be submitted by the BAMC, the bank or the Bank of Slovenia. The interministerial committee (consisting of eight members appointed by the Government and the Bank of Slovenia) will assess business strategy of the banks. The government will issue an executive act that determines the requirements that banks must ensure, such as approvals of loans to small and medium-sized companies, the use of cash assets received, the remuneration, the level of assets, distribution of dividends, etc.

The BAMC shall disclose to the public all information that is relevant to the company's operations, as applies to joint stock companies, excluding data which are considered confidential in accordance with the act regulating banking. The BAMC shall report annually to the National Assembly and prepare annual financial statements and a business report (the balance of assets, liabilities, revenues and expenses).

\section{The creation of the BAMC could speed up the resolution of NPLs but the process has to be transparent and independent}

There are a number of advantages to the creation of the BAMC to purchase troubled assets. First, the remaining cleaned-up bank will be able to focus on normal banking operations, while the BAMC will specialise in the recovery of bad assets. Concentration of all bad loans in one bank can be particularly helpful in Slovenia, where companies have multiple banking relationships that create obstacles to debt restructuring due to difficult negotiations between multiple parties. Second, transparently executed, cleaning-up of banks' portfolios will provide them with a fresh start, simplify their access to the capital market, and increase their chances to be sold to a strategic private investor. Importantly, the BAMC should be used to dispose transferred assets rather than to undertake a corporate restructuring of underlying companies. The rare example of successful management of corporate restructuring is that of Sweden in the 1990s where the success was guaranteed by professional management, political independence, appropriate funding, adequate bankruptcy laws and transparency in operations and processes (Klingebiel, 2000).

In light of these advantages, a number of OECD countries have established asset management companies. Ireland and Spain have decided to transfer bad assets to a centralised asset management company, Switzerland has established an off-balance sheet special purpose vehicle tailored for UBS, and Denmark has chosen to separate a bad bank from a good bank as a tool of bank resolution (Table 2). In light of previous experience, both stages in the work of the BAMC - the selection and pricing of assets to be transferred and their subsequent management - should be conducted in an independent, accountable and transparent way. 
Table 2. Bad bank practices in OECD countries

\begin{tabular}{|c|c|c|c|c|c|c|c|}
\hline & Slovenia & Denmark & Germany & Ireland & Spain & Sweden & Switzerland \\
\hline Name & $\begin{array}{l}\text { Bank Asset } \\
\text { Management } \\
\text { Company } \\
\text { (BAMC); Druzbo } \\
\text { za upravljanje } \\
\text { terjatev bank } \\
\text { (DUTB) }\end{array}$ & $\begin{array}{l}\text { Amagerbanken, } \\
\text { subsidiary of the } \\
\text { Financial Stability } \\
\text { Company }\end{array}$ & $\begin{array}{l}\text { Bundesanstalt für } \\
\text { Finanzmarktstabili } \\
\text { sierung (Federal } \\
\text { Agency for } \\
\text { Financial Market } \\
\text { Stabilisation, } \\
\text { FMSA) }\end{array}$ & $\begin{array}{l}\text { National Asset } \\
\text { Management } \\
\text { Agency (NAMA) }\end{array}$ & $\begin{array}{l}\text { Sociedad de } \\
\text { Gestión de } \\
\text { Activos } \\
\text { procedentes de la } \\
\text { Reestructuración } \\
\text { Bancaria } \\
\text { (SAREB) }\end{array}$ & $\begin{array}{l}\text { Securum and } \\
\text { Retrieva }\end{array}$ & StabFund \\
\hline $\begin{array}{l}\text { Date of } \\
\text { establishment }\end{array}$ & 2012 & 2011 & 2008 & 2009 & 2012 & 1992 & 2008 \\
\hline Expected duration & 5 years & It is a new bank & $\begin{array}{l}\text { When resolution } \\
\text { is complete }\end{array}$ & $\begin{array}{l}\text { Till the Minister for } \\
\text { Finance } \\
\text { determines that its } \\
\text { mission is } \\
\text { completed }\end{array}$ & 15 years & $\begin{array}{l}15 \text { years, but } \\
\text { liquidations were } \\
\text { completed in } 1997\end{array}$ & $\begin{array}{l}8 \text { years, } \\
\text { extendable to } 12\end{array}$ \\
\hline $\begin{array}{l}\text { Type of bad } \\
\text { assets to be } \\
\text { transferred }\end{array}$ & Not clear & $\begin{array}{l}\text { All assets of the } \\
\text { bank that is } \\
\text { wound-down }\end{array}$ & $\begin{array}{l}\text { No restriction } \\
\text { concerning asset } \\
\text { classes }\end{array}$ & $\begin{array}{l}\text { Loans for land } \\
\text { and development } \\
\text { purposes and } \\
\text { associated } \\
\text { property loans }\end{array}$ & $\begin{array}{l}\text { Mainly loans to } \\
\text { real estate } \\
\text { developers and } \\
\text { foreclosed real } \\
\text { estate }\end{array}$ & $\begin{array}{l}\text { Real estate } \\
\text { assets }\end{array}$ & $\begin{array}{l}\text { Securitised loans, } \\
\text { including sub- } \\
\text { prime mortgage } \\
\text { loans }\end{array}$ \\
\hline $\begin{array}{l}\text { Pricing of bad } \\
\text { assets, discount }\end{array}$ & Not clear & $\begin{array}{l}\text { The transfer sum } \\
\text { was considerably } \\
\text { lower than the } \\
\text { existing book } \\
\text { value less further } \\
\text { loan impairment } \\
\text { charges }\end{array}$ & $\begin{array}{l}\text { Transferring } \\
\text { banks are obliged } \\
\text { to compensate for } \\
\text { the losses }\end{array}$ & $\begin{array}{l}\text { Discount } 57 \% \text {. } \\
\text { Theoretically, } \\
\text { long-term } \\
\text { economic value, } \\
\text { but closely } \\
\text { aligned to the } \\
\text { current market } \\
\text { value of collateral }\end{array}$ & $\begin{array}{l}\text { Long-term } \\
\text { economic value. } \\
\text { Discounts } \\
\text { (46-63\%) based } \\
\text { on the } \\
\text { independent due } \\
\text { diligence }\end{array}$ & $\begin{array}{l}\text { Assets were } \\
\text { transferred at } \\
\text { book value }\end{array}$ & $\begin{array}{l}\text { Book value with } \\
\text { discounts. Pricing } \\
\text { rules are public } \\
\text { information }\end{array}$ \\
\hline Financing & $\begin{array}{l}\text { Government } \\
\text { guaranteed bonds }\end{array}$ & $\begin{array}{l}\text { Subject to bank } \\
\text { capital } \\
\text { requirements }\end{array}$ & $\begin{array}{l}\text { Own funds and } \\
\text { loans issued by } \\
\text { the Ministry of } \\
\text { Finance }\end{array}$ & $\begin{array}{l}\text { Equity }=0.8 \% \text { of } \\
\text { assets }\end{array}$ & $\begin{array}{l}10 \% \text { equity. } \\
\text { Private equity, } \\
\text { perhaps } \\
\text { government } \\
\text { equity and } \\
\text { government- } \\
\text { guaranteed bonds }\end{array}$ & $\begin{array}{l}\text { Deliberate } \\
\text { overcapitalisation } \\
\text { enabled the asset } \\
\text { management } \\
\text { companies to } \\
\text { carry out their } \\
\text { salvage } \\
\text { operations } \\
\text { autonomously }\end{array}$ & $\begin{array}{l}10 \% \text { equity from } \\
\text { UBS and } 90 \% \\
\text { with Swiss } \\
\text { National Bank } \\
\text { loan. Public } \\
\text { guarantees }\end{array}$ \\
\hline $\begin{array}{l}\text { Role of } \\
\text { independent } \\
\text { experts in } \\
\text { valuations }\end{array}$ & None & $\begin{array}{l}\text { Two auditors } \\
\text { appointed by the } \\
\text { Institute of State } \\
\text { Authorised Public } \\
\text { Accountants }\end{array}$ & None & $\begin{array}{l}\text { Competitive public } \\
\text { procurement } \\
\text { process to find } \\
\text { professional } \\
\text { advisors to carry } \\
\text { out the due } \\
\text { diligence }\end{array}$ & $\begin{array}{l}\text { Valuations by } \\
\text { external } \\
\text { consultancy firms } \\
\text { under supervision } \\
\text { of European } \\
\text { Central Bank and } \\
\text { International } \\
\text { Monetary Fund }\end{array}$ & $\begin{array}{l}\text { Bank Support } \\
\text { Authority, } \\
\text { independent of } \\
\text { the Ministry of } \\
\text { Finance and the } \\
\text { central bank }\end{array}$ & No decision role \\
\hline
\end{tabular}

Source: Law on Slovenia's Measures to Strengthen Bank Stability, September 2012; Danmarks Nationalbank (2011), Financial Stability 2011; Act on the Establishment of a Financial Market Stabilisation Fund (Germany); National Asset Management Agency (Ireland) www.nama.ie; and OECD (2011), OECD Economic Surveys: Switzerland 2011, Ergungor, O.E. (2007), "On the Resolution of Financial Crises: The Swedish Experience", Policy Discussion Papers, No. 21, Federal Reserve Bank of Cleveland; and OECD Economics Department.

The choice and pricing of non-performing assets and the subsequent identification of the resulting equity gap are crucial. The authorities prefer a tailor-made approach that would differ from asset to asset and bank to bank. However, best practice suggests that, to avoid adverse selection problems, the authorities have to define asset classes that can be transferred and banks should transfer either all or none of the assets in a given category. Moreover, to motivate banks to be transparent, the transfer of assets should be structured as a one-off opportunity to get rid of bad assets. Current law states that transferred claims have to be priced according to their "real long-term economic value". Even though the process of pricing has to be agreed with the European Commission within the State Aid guidelines of the Directorate General for Competition, the authorities could have incentives to overestimate the price of transferred assets in order to 
minimise immediate recapitalisation costs of banks. This approach transfers the problem to the BAMC and pushes the cost recognition into the distant future.

To determine a credible discount rate for the ring-fenced assets, international best practice is that duediligence analysis needs to be performed. To increase its credibility, it should be conducted not by one consultancy, but several, in cooperation with international institutions. For example, in Spain the due diligence was performed by six firms (Oliver Wyman, Ernst\&Young, KPMG, PwC, Deloitte and the Boston Consulting Group) while macroeconomic scenarios were defined in cooperation with the European Commission, the European Central Bank, the European Banking Authority and the International Monetary Fund. In contrast, the due-diligence analysis of key Slovenian banks was carried out by a single consultancy firm (European Resolution Capital), chosen because its offer was the cheapest. The main results were not made public, but its methodology appears to be not sufficiently forward-looking as discussed earlier. To foster the credibility of the BAMC, a new bottom-up due diligence exercise should be performed, accompanied by a top-down stress test by the central bank. The main underlying assumptions and results of both exercises should be made public so as to reduce market uncertainties regarding the needs for public recapitalisation.

Once the equity gap is identified, banks need to be recapitalised. It is important that banks are recapitalised with cash rather than state-guaranteed bonds, because non-cash recapitalisation would postpone cost recognition for the budget and further reinforce the negative feedback loop between the solvency of the government and the banks. Hence, capital ratios of distressed but viable banks should be increased, preferably by issuing shares, as advised by the ECB (2012). To reduce the need for tax-payer revenues to bail out failing banks, the authorities should also consider a bail-in option, which would also help reducing the negative feedback loops between government finances and the financial systems (Financial Stability Board, 2011).

NLB and the NKBM have bought their hybrid capital instruments at a discount of 40-50\%. However, holders of subordinated debt should also absorb losses of banks that are resolved or are recapitalised by the government. The amount of subordinate debt is not negligible: about 3\% of total banking assets. Fiscal costs could be reduced further by also imposing losses on senior debt for banks put into resolution. It is important to stress that bail-in may increase the funding costs of Slovenian banks perceived as being at risk of becoming non-viable in the future and thus subject to future bail-ins, deterring potential investors. Hence, it is important to carefully design the bail-in strategy to reduce that risk (IMF, 2012b).

The current legislation gives very broad powers to the BAMC to undertake bank restructuring that goes beyond traditional functions of an asset management company. This might raise concerns if the BAMC uses its powers to oblige banks to convert debt into equity and, hence, both banks and their debtors would be owned by the state. A special warning should be issued regarding the power of the BAMC to determine requirements that participating banks must ensure, such as, for example, lending to SMEs. Such an approach closely resembles the decision of the Japanese government to require recapitalised banks to increase lending to small and medium-sized enterprises (SMEs), leading to large non-performing loans in this sector (Hoshi and Kashyap, 2010). If the government plans to privatise SOBs, such requirements can be perceived as continued political interference and would discourage potential investors. Although other governments have imposed a number of restrictions on banks that required state assistance, they usually aimed to increase retained earnings by limiting salaries and dividend distribution.

To be robust, the corporate governance of the BAMC must be backed by strong independence and accountability. The current law could set the stage for independent management because it foresees a public call for applications and the possibility of competitive salaries to attract reputable managers. Some managers have already been appointed. A potential weakness is that non-executive directors of the management board and members of an inter-ministerial committee, who will assess the business strategy of banks, do not have to fulfil any professional requirements and could hold political positions. Moreover, 
there is a potential conflict of interest as the Ministry of Finance will combine the roles of owner and supervisor of the BAMC, while the role of the Bank of Slovenia in the supervision of the BAMC is unclear.

Strengthening financial independence is another issue. If BAMC is financed by guaranteed debt with almost no equity, this reduces the immediate impact on the budget deficit, but it creates poor incentives for managers who will be reluctant to sell assets at a loss in order to avoid that state guarantees are effectively enforced and lead to budgetary expenditures. The current law does not specify what happens with losses or profits of the BAMC at the end of its mandate. Even though BAMC debt is guaranteed by the state, the absence of capital buffers will also deter private investors who could be interested in buying BAMC bonds. The Swedish experience demonstrates that asset management companies require sufficient funding and even have to be overcapitalised in order to be autonomous and free from political interference (Ergungor, 2007). Hence, the BAMC should be sufficiently capitalised, preferably with the participation of private investors. Finally, the five year mandate appears rather short and could be extended to 15 years (as is the case in Ireland, Spain and Sweden), notably to minimise taxpayer costs. Concomitantly, the currently foreseen requirement that all assets that are not disposed by the BAMC within its term will be transferred to the recently created sovereign holding company should be scrapped as this could potentially lead to a permanent postponement of the crisis resolution. There is also no reason to believe that the holding would be better able to manage impaired assets than the BAMC.

The independence of the BAMC requires full transparency in order to make it accountable. The law foresees annual reports of the BAMC to parliament, which is not sufficient in a crisis environment when the situation changes very rapidly. The BAMC should be required to disclose information on the transferred assets, including refinancing, restructuring and disposal. The Irish National Asset Management Agency publishes news on its activity and quarterly reports on its webpage, while the US Treasury Department that manages the Troubled Asset Relief Program provides daily updates. Hence, the creation of the webpage that transparently explains the process and publishes at least quarterly reports would be essential.

\section{Restructured banks should be promptly privatised}

Since the crisis has affected the solvency of SOBs much more than that of private foreign institutions, and, to a lesser extent, private domestic banks, this raises the question about their ability to prevent future misallocation of credit. As previously discussed, SOBs have the largest share of NPLs, suggesting inadequate risk management. Moreover, the two largest SOBs - Nova Ljubljanska Banka (NLB) and Nova Kreditna Banka Maribor (NKBM) - appear to be among the least efficient banks in the country, particularly on a profit basis, as analysed in the chapter on foreign investment, governance and economic performance of the 2011 Economic Survey of Slovenia (OECD, 2011b). This result is not surprising as there is a large cross-country literature that shows that state ownership of banks is less efficient than private ownership, while privatisation and foreign bank entry have a salutary effect on banking sectors (Bonin et al., 2005). Hence, the prevailing consensus calls for privatisation of SOBs.

The Slovenian authorities have announced that they are willing to reduce their share in the largest three SOBs to the blocking minority of $25 \%$ plus one share. The decision to privatise is welcome, but international experience shows that partial privatisations thwart true reforms and often lead to additional recapitalisation (Andrews, 2010). Moreover, the residual possibility of state intervention will deter foreign investors.

In 2001, the government already announced the privatisation of the two largest banks (NLB and NKBM) through a tender which was only partly successful. Due to public outcry against selling the "family silver" to foreigners, the Belgian bank KBC was allowed to acquire only $34 \%$ of shares in NLB. According to the tacit agreement with $\mathrm{KBC}$, it appears that the government promised to allow $\mathrm{KBC}$ to 
become the majority shareholder. Yet, the negotiations failed in 2004 and $\mathrm{KBC}$ proclaimed that it would turn from a position of strategic investor to the position of portfolio investor. As to the NKBM, only three institutions that showed interest met the minimal requirements to be taken seriously as bidding offers: Italian bank Unicredito, Austrian Bank Austria and Activa Group. Government representatives stated publicly their disappointment that no "major" bank expressed interest in NKBM and one year later decided that none of the bidders met the necessary conditions (Lindstrom and Piroska, 2007).

Such an unsuccessful previous experience with privatisation means that the government will need to work hard to attract reputable foreign investors. Privatisation of SOBs should follow immediately after the cleaning-up of their portfolios by transferring bad assets to the BAMC. All successful bank privatisations have been achieved through some form of share sale and have involved a strong financial institution as a significant strategic shareholder. This can be achieved through a sale by competitive and transparent tender. Most likely such an investor will be foreign. As with any change in bank ownership, the supervisory authority should ensure that the new owners are fit and proper, management is competent and experienced, the source of capital is verified, and the business plan is viable.

\section{Deleveraging of the corporate sector}

International experience suggests that crises preceded by credit booms tend to be followed by sizeable deleveraging (Tang and Upper, 2010). Deleveraging will inevitably hurt growth, but it is a necessary process to both reduce risks that over-indebtedness poses to the economy and to lay the foundations for a sound recovery. The issue is not to slow down or impede this process, but to mitigate the negative impact on activity. To achieve a smooth deleveraging of the non-financial corporate sector, three conditions should be fulfilled. First, it is essential to repair bank balance sheets and to ensure the recapitalisation of viable banks, as discussed earlier. If banks are not adequately capitalised and burdened with bad loans, they are likely to shrink their assets faster than desired in order to increase their capital ratios. Moreover, there is a risk that banks have incentives to "evergreen" bad loans and to "gamble for resurrection" by issuing high-risk high-return loans (Caballero et al., 2008). Second, smooth deleveraging requires an efficient insolvency framework to ensure that viable but distressed enterprises are restructured while insolvent firms are swiftly liquidated. Third, corporate deleveraging should be achieved not only via a decrease in debt, but also via an increase in equity, to avoid too negative an impact on activity.

The deleveraging has barely started in Slovenia. Even though there is a sizable drop in the amount of outstanding credit to non-financial corporations, which compares poorly in international perspective and illustrates the weakness of the economic situation in Slovenia (Figure 8), the decline in equity has offset a large part of it, resulting in only a small decline in debt-to-equity ratios (Figure 2). New loans decline, notwithstanding the economic sector. To spur loan growth, the authorities introduced a tax on banks' balance sheets in mid-2011 that is expected to last till end-2014. A tax rate of $0.1 \%$ is applied on banks' assets and the levy can be reduced if banks grant loans to non-financial entities (and the conditions to decrease the tax base were tightened in December 2012). However, it is not wise to try to delay the necessary deleveraging and the bank levy should be repealed. In any case, the tax is not effective as weak credit activity is caused by poor bank health, decline in foreign funding not fully compensated with Eurosystem liabilities (Figure 9) and weak loan demand since 2011 (Figure 10). Previous international experience shows that deleveraging lasts between five and ten years with an average of 8.3 years (Ruscher and Wolff, 2012). 
Figure 8. Outstanding loans to non-financial corporations

Index, June $2010=100$

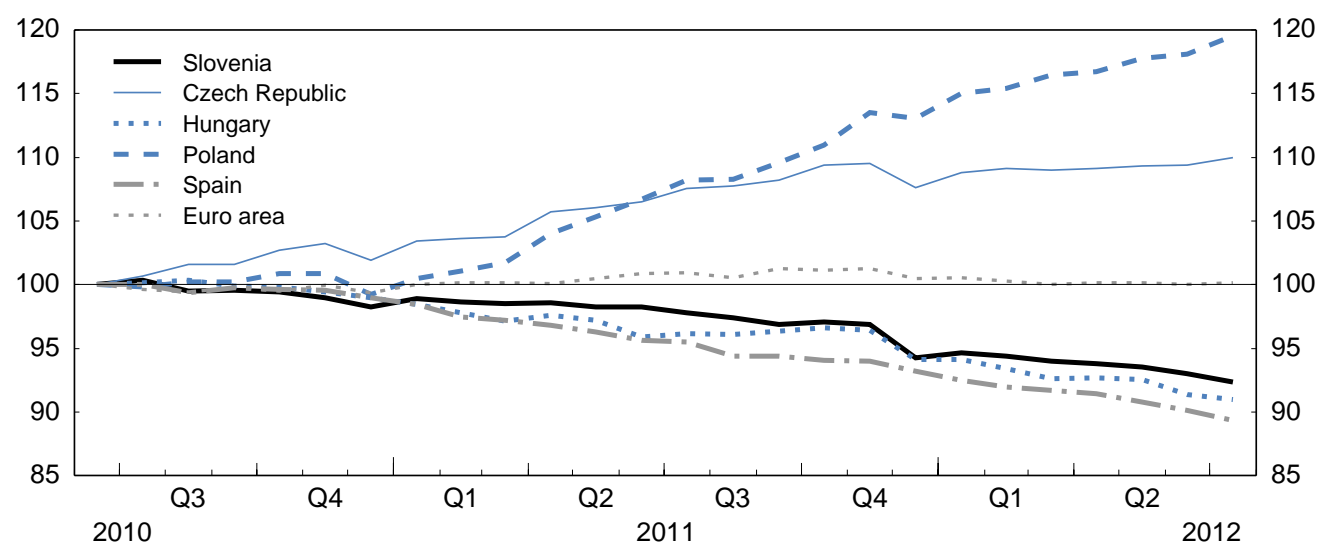

Source: MNB (2012), Report on Financial Stability, November, Magyar Nemzeti Bank and Bank of Slovenia.

Figure 9. Development of foreign liabilities and liabilities from the Eurosystem

Thousand euros

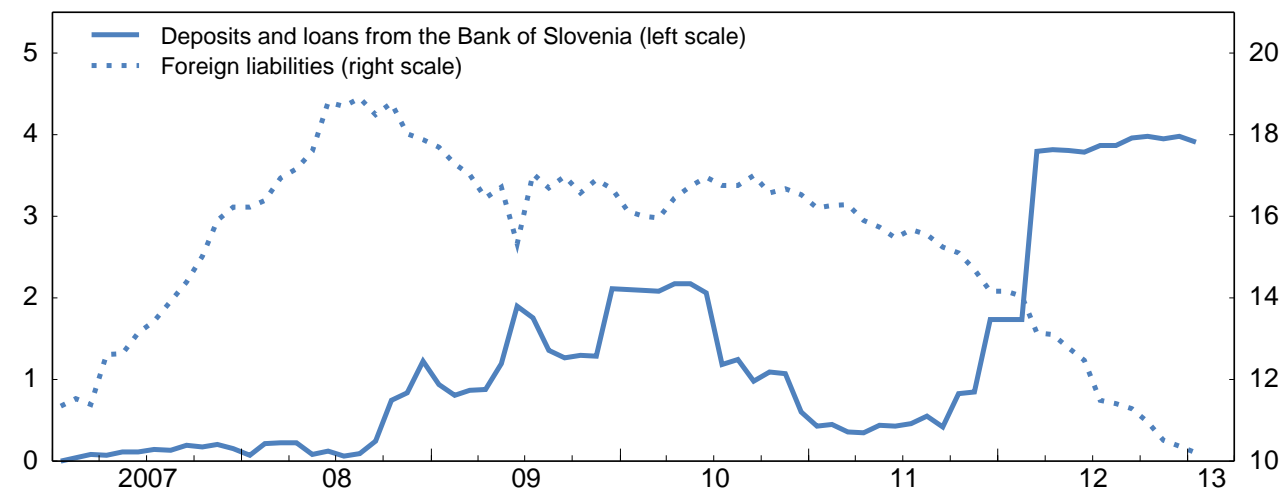

Source: Bank of Slovenia (2013), Monthly Bulletin, February.

Figure 10. Credit conditions and credit demand evolution

Net percentage, ${ }^{1}$ positive numbers indicate tightening of credit standards or increased loan demand
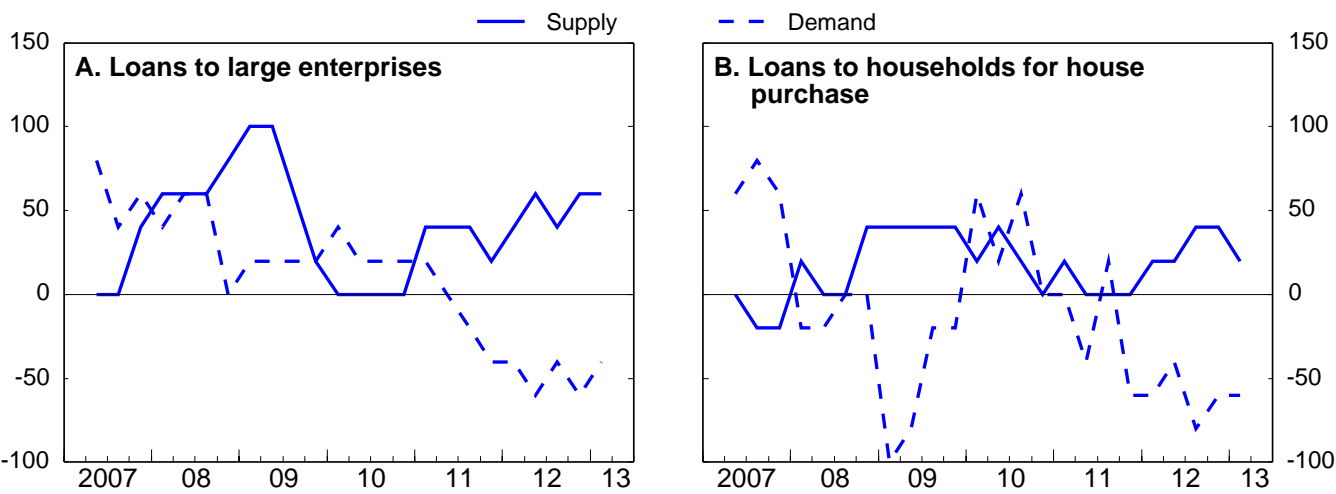

1. The net percentage is the frequency of tightened minus that of eased or reverse conditions over the previous three months based on the opinions of senior loan officers of a representative sample of banks.

Source: ECB (2013), "Bank Lending Survey”, Statistical Data Warehouse, European Central Bank, March. 
The duration of deleveraging can be particularly long for countries whose loan growth was financed by cross-border loans instead of deposits. The loan-to-deposit ratio in Slovenia, at around 136\% (October 2012), is high in international comparison (Figure 11). In a number of countries banks are decreasing their loan-to-deposit ratio either due to new regulation (the authorities have limited this ratio to 110 and $120 \%$ in respectively Austria and Portugal) or due to financial constraints. Slovenian banks have also reduced their reliance on foreign funding and domestic banks reported a loan-to-deposit ratio of $113 \%$ in October 2012, while the ratio for foreign banks is $180 \%$. However, to prevent the return of external risks in the future, setting a $120 \%$ loan-to-deposit target for banks could be an option. It will concern primarily foreign banks and it should be reached very gradually to avoid unduly hurting economic activity and disorderly withdrawal of funding.

Figure 11. Loan-to-deposit ratio in the euro area has declined ${ }^{1}$

Loans to banks and non-banking sector/non-banking sector deposits

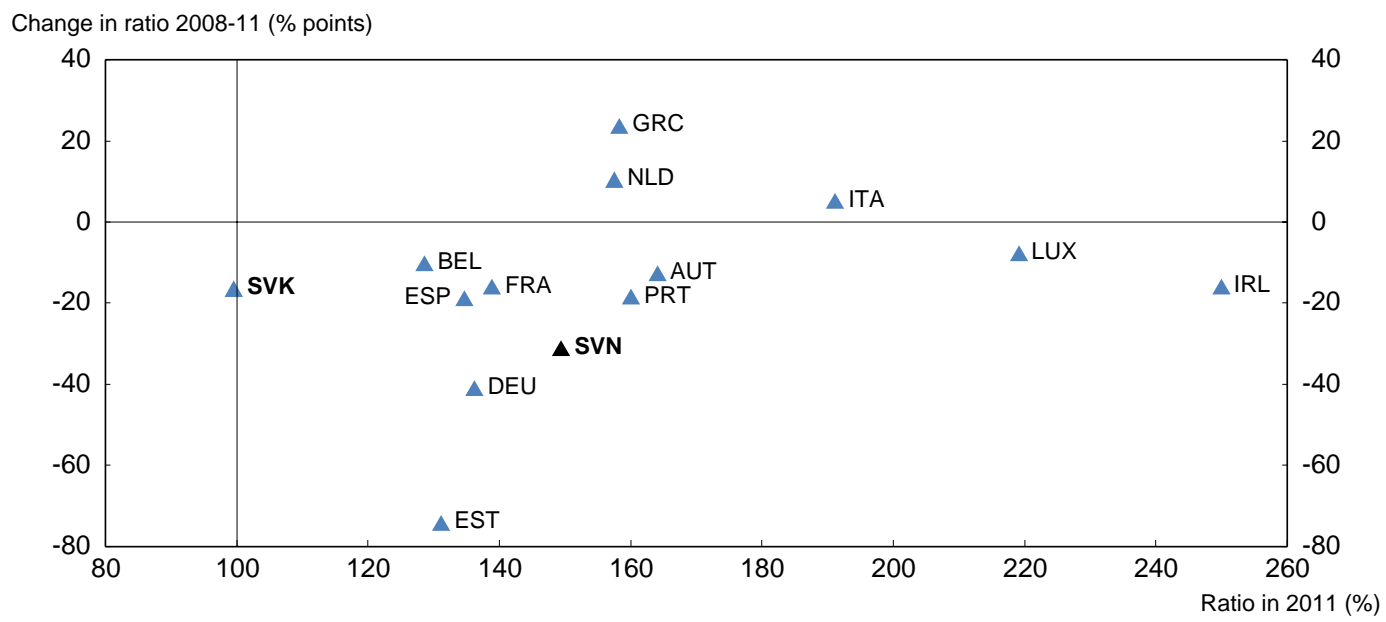

1. Domestic banking groups and stand-alone banks, foreign controlled subsidiaries and branches. Loans and receivables including finance leases and total deposits other than from credit institutions, both in per cent of total assets.

Source: ECB (2013), "Statistics on Consolidated Banking Data", Statistical Data Warehouse, European Central Bank, January.

\section{Inefficient insolvency procedures are the main obstacle to corporate NPLs resolution}

In Slovenia, liquidation is often the only option for distressed businesses and restructuring is rare and difficult due to a number of obstacles. First, many firms (particularly large ones) have banking relationships with many banks simultaneously, which complicates negotiations between different parties. Banks are not always aware about the credit history of their clients with other banks and might learn too late about firms' arrears at other banks. Firms do not disclose their distressed situation to all banks simultaneously but try to negotiate individually with different banks. Second, owners of firms do not have the cash to provide additional capital, particularly in the case of firms that were bought during leveraged buyouts and whose owners are highly leveraged themselves. To deal with this problem banks rely on debtequity swaps for the case of the firms with the best prospects, but this practice remains rare. Third, the insolvency framework is long and inefficient, resulting in very low recovery rates.

\section{Debtors and creditors should resort early to insolvency procedures}

The insolvency framework involves a number of possible pathways between the start of a new company, early warning systems, potential financial problems, firm survival due to reorganisation (out-ofcourt or in-court) and liquidation in the case of the failure of the above preventive measures (Figure 12). The European Union encourages national authorities to design insolvency procedures that are quick and 
easy - lasting no more than a year. According to the World Bank 2012 Doing Business indicators, it takes on average 24 months to complete a standard bankruptcy procedure (with a main secured creditor and several unsecured ones) in Slovenia. By contrast, it is possible to do this in less than one year in a number of OECD countries, including Belgium, Canada, Finland, Ireland, Japan or Norway (Figure 13). More importantly, the duration is much longer for large complex businesses with numerous creditors and it usually takes three or more years in such cases. Unfortunately, most large corporate NPLs belong to this category and courts face many difficulties to resolve complicated cases.

Figure 12. Overview of the insolvency process

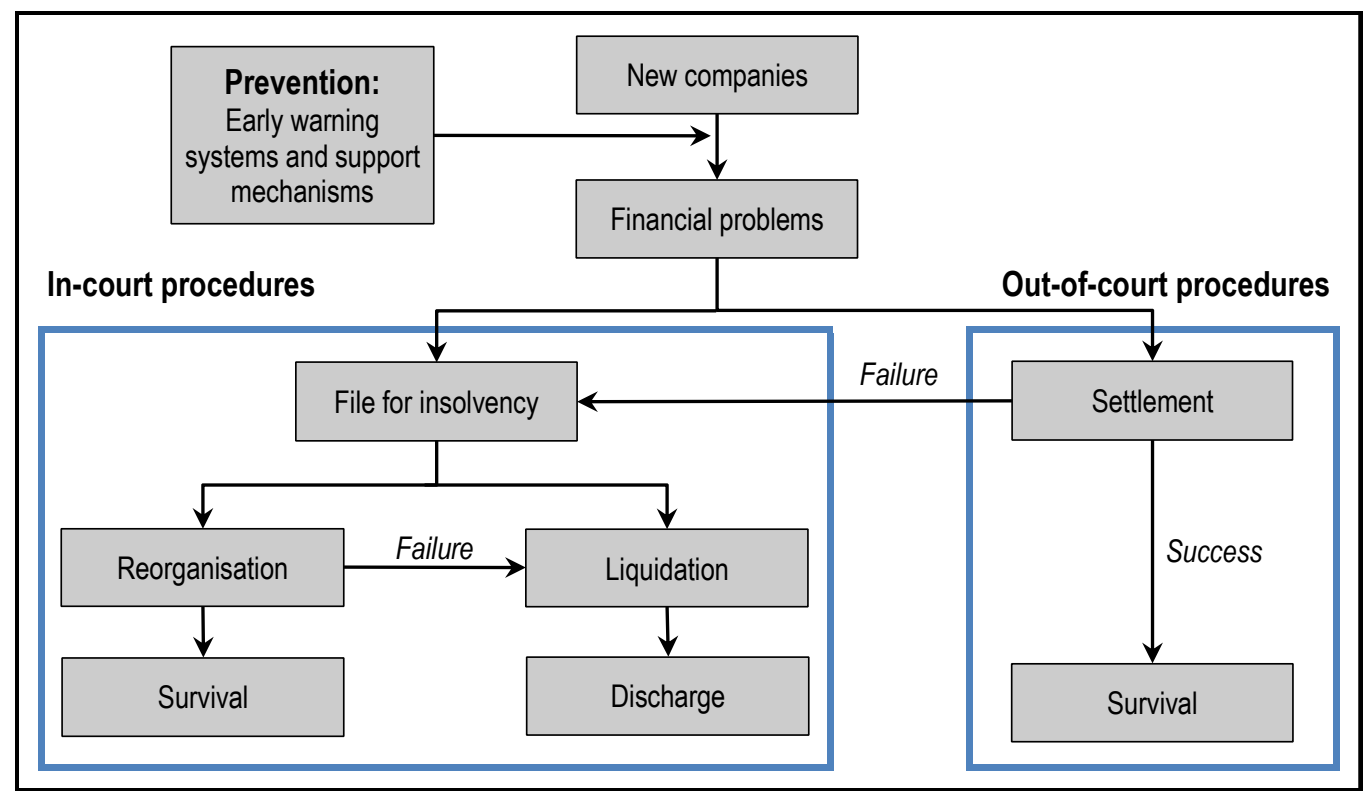

Source: Based on European Commission (2011), "A Second Chance for Entrepreneurs: Prevention of Bankruptcy, Simplification of Bankruptcy Procedures and Support for a Fresh Start”, Final Report of the Expert Group. 
Figure 13. Efficiency of the insolvency law

$2012^{1}$

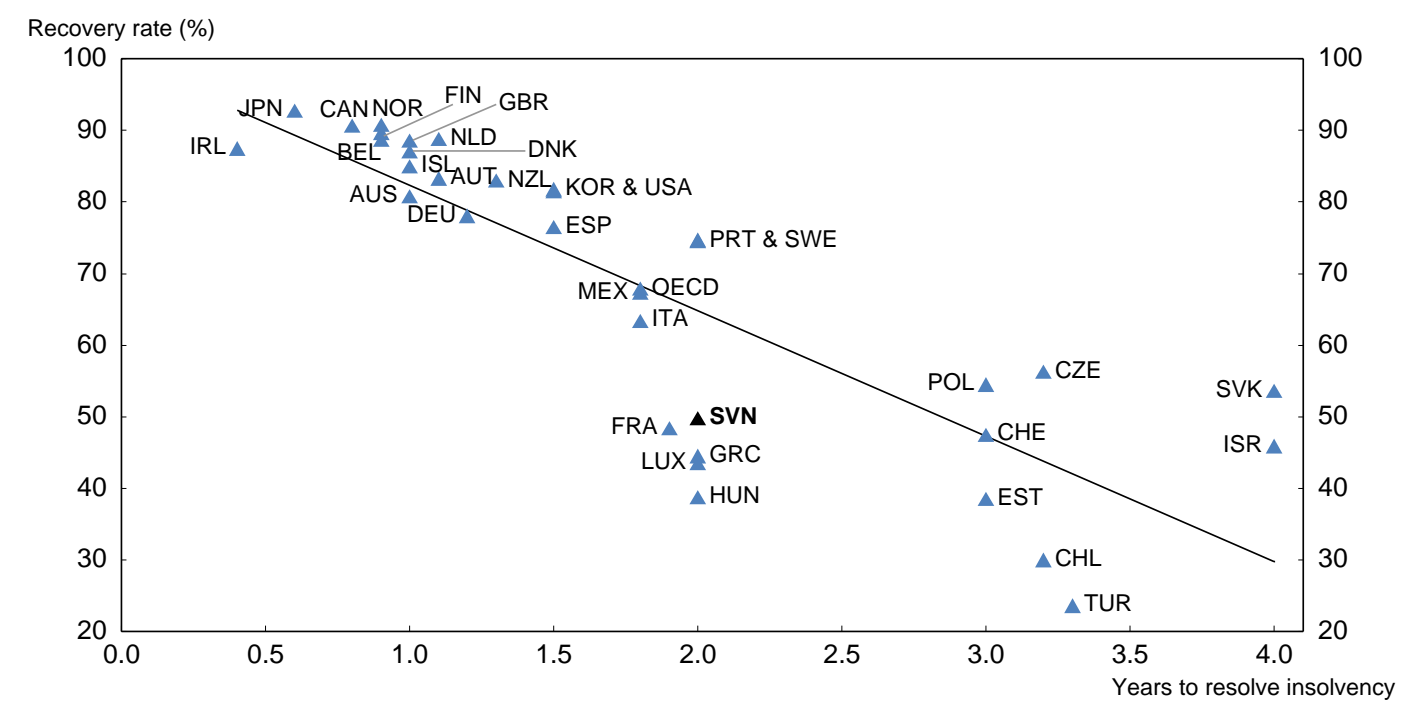

1. To make the data comparable across economies, several assumptions about the business and the case are used. For details see: www.doingbusiness.org/methodology/resolving-insolvency. The OECD aggregate is an unweighted average.

Source: World Bank (2012), Doing Business 2013: Smarter Regulations for Small and Medium-Size Enterprises, World Bank Group.

The duration of insolvency procedures is crucial because it is negatively correlated with recovery rates: the slope of the line in Figure 13 suggests that an additional year spent on litigation decreases the recovery rate by 16 percentage points. While Slovenian investors can recover only $51 \%$ of assets, best practices show that it is possible to achieve recovery rates above $90 \%$ (Canada, Japan and Norway). Such high rates are achieved by rapid bankruptcy procedures that last 6,8 and 9 months, respectively (Figure 13). Hence, decreasing the duration of the insolvency procedures must be the priority of the bankruptcy framework. The statistics of the Slovenian Ministry of Justice show a positive trend, as the share of bankruptcy cases that take more than two years decreased from $21 \%$ in 2009 to $10 \%$ in 2011 . Unfortunately, these statistics are not representative for insolvencies that result in NPLs, and there are no signs of improvement for the latter cases.

One of the main reasons why bankruptcy procedures take a long time and the recovery rate is low is the fact that they are initiated too late, usually when it is impossible to save the enterprise. According to Slovenian law, there are two alternative definitions of insolvency: 1) liquidity approach (when the company is late for more than two months in meeting its liabilities in a total amount exceeding $20 \%$ of the amount of total liabilities) and 2) balance sheet approach (if the value of assets is smaller than the sum of liabilities). Yet, the emphasis is much more on the first approach and a company that is balance sheet insolvent can effectively challenge its creditor in court if it can demonstrate that it still can meet its obligations. Insolvent companies that succeed in refinancing their credits can stay insolvent for prolonged periods of time before applying for bankruptcy and this would be in line with the current legislation. Such a situation should be changed and companies that are balance sheet insolvent should be obliged to apply for bankruptcy.

Even when the law obliges insolvent firms to apply for bankruptcy (otherwise they are liable for the financial damages arising from the delay), many firms postpone the announcement of their insolvency, try to buy time and gamble for resurrection. De facto, there are no sanctions against such fraudulent behaviour. It is important to ensure that the existing law is enforced and firms should be encouraged to apply for bankruptcy as early as possible. Otherwise, the debtor should carry civil and, where appropriate, criminal 
responsibility, as is the case in France or Germany. To motivate entrepreneurs to apply early, the bankruptcy procedures should distinguish between honest and fraudulent bankruptcy and honest businessmen should receive a fresh start after the end of bankruptcy procedures (European Commission, 2011a). Judges should be trained in how to act in cases of fraudulent bankruptcy.

\section{The legal framework for in-court and out-of-court restructuring should be improved}

International experience shows that in-court reorganisation, such as "Chapter 11" in the United States, is one of the most efficient procedures. Although the Slovenian legislation has proposed such an option since 1999 (insolvency compulsory settlement procedure), it is rarely used. In 2011, there were only 26 cases resolved by the in-court restructuring procedures. There are a number of reasons for this. According to the Business Dynamics Survey 2010, businesses are not always aware of this option (European Commission, 2011b). Even if borrowers are aware, the existing in-court restructuring procedures are considered to be too costly and complex, which discourages particularly small and medium enterprises that are left with bankruptcy as the only viable option. A plan to introduce fast-track simplified procedures for micro enterprises and sole proprietors is a welcome step in the right direction.

Firm reorganisation can also be achieved by voluntary out-of-court restructuring that provides a speedy and cost-effective tool to achieve debt settlement (EBCI, 2012). Although allowed under the Slovenian insolvency law, it is not explicitly regulated and no official data is collected on these procedures. According to the Business Dynamics Survey 2010, the average time of an out-of-court restructuring is 8.5 months which is rather high in international comparison (European Commission, 2011b). To speed up this process, out-of-court restructuring should be regulated either by a set of principles or by a law, in line with the INSOL principles (International Association of Restructuring, Insolvency and Bankruptcy Professionals). If creditors lend money to businesses under such procedures, they should receive priority in the payment of claims, making it more likely that distressed businesses would get new loans.

\section{Liquidation of failed enterprises should be speeded up}

If a company is not viable, it has to be liquidated under the court supervision. The authorities can take a number of steps to render these bankruptcy procedures more efficient. One of the possible tools can be the establishment of time limits. Currently, the law limits the evaluation stage of the bankruptcy procedures to seven months, but this limit is often exceeded. It is important to ensure that the current legislation is enforced and, then, to attempt to decrease the time of this procedure even further. Moreover, the World Bank advises to introduce a time limit to the overall bankruptcy procedure, including the litigation stage. In exceptional cases, the duration could be changed at the discretion of a judge. The efficiency of the bankruptcy procedures is related to adequate staffing of courts and professionalism of judges and receivers. According to the 2012 Economic Freedom Index, courts are understaffed, but experts agree that there is also scope for increasing efficiency of judges. The establishment of judges that specialise in bankruptcy procedures is a welcome step forward.

Another way to increase the efficiency of the system is to render it more transparent, thus, increasing the accountability of judges. Slovenia has made impressive progress in this respect. Information about initiated and resolved bankruptcy cases is published online. Moreover, in 2008, the Supreme Court established a computerised case management system (Judicial Data Warehouse) that collects data on a large number of indicators that, on the one hand, help judges to reach faster and fairer judgments and, on the other hand, permits a comparison of the performance of similar courts. This system appears to improve the management of human resources between courts, having a positive effect on the speed of litigations and reducing the backlog. 
The judicial decisions should be not only swift, but also fair. Yet, according to the 2012/13 Global Competitiveness Report (WEF, 2012), the Slovenian judiciary is not independent from influences of members of government, citizens, or firms. Among OECD countries, only six members show larger external influences (Czech Republic, Greece, Hungary, Korea, Mexico and Turkey). The 2012 Economic Freedom Index documents a gradual progress, but it also shows that the judicial framework remains vulnerable to political interference. Recent media reports point to some cases where judges and receivers have improper ties and several investigations were launched in September 2012. It is not surprising, that if the judicial process is perceived to be partial, debtors and creditors are discouraged from resorting to it. One can hope that the computerised case management system will be used to increase the accountability of judges and control fairness of their decisions.

\section{Development of the equity market can help smooth deleveraging}

In the corporate sector, debt-to-equity ratios have fallen driven by a decline in lending, the largest construction companies went bankrupt and the state has transferred some assets to the transportation company DARS. But the deleveraging of the non-financial sector should be achieved not only through debt reduction but also by raising equity on the stock market and attracting foreign capital to viable enterprises. This would not only smooth the deleveraging of Slovenian non-financial corporations, but would also strengthen their corporate governance and market discipline. Foreign direct investment has been low and public ownership remains high in Slovenia (Figure 14). Hence, privatisation of non-financial corporations supported by the definition of a clear asset management strategy, underpinned by a well-defined distinction between strategic and non-strategic holdings, could attract valuable equity. Alternatively, banks could contribute to repair the balance sheets of ailing businesses through debt-to-equity swaps. Yet this would increase the already large state ownership in the economy even more and, given Slovenia's poor governance, delay necessary deleveraging.

Figure 14. Public ownership is large and foreign direct investment is low

Per cent of GDP, 2011
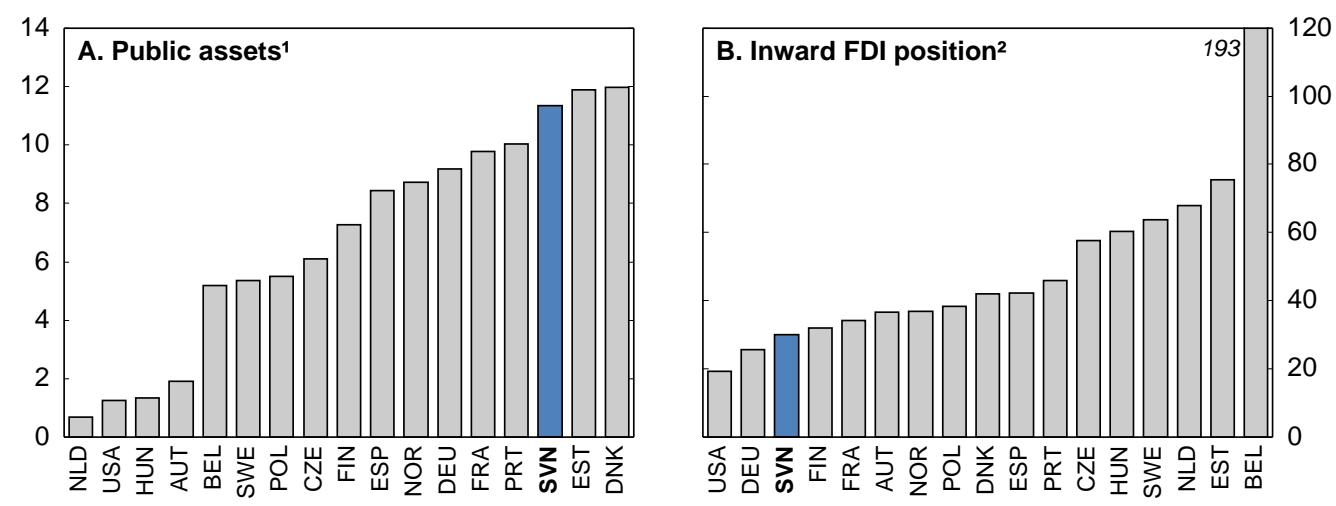

1. As represented by "other equity" from the consolidated financial accounts of the general government sector. This covers financial equity assets and excludes quoted and unquoted shares in companies and mutual fund shares. Data is only available for a limited number of OECD countries.

2. The inward foreign direct investment (FDI) position relates to the stock of investments by non-resident investors in the reporting country at the end of the year. For comparison purposes, the same countries are shown as in panel A.

Source: OECD (2013), OECD National Accounts Statistics and International Direct Investment Statistics (databases), March. 
The development of the stock market is stifled by the high share of state ownership in the ten largest listed companies, limited protection of minority shareholders and ineffectiveness of supervision by the Securities Market Agency (SMA). As mentioned earlier, the large share of NPLs is attributed to financial holding companies used in privatisation through leveraged buy-outs and the underlying companies that were subject to buy-outs. There are concerns that a number of high profile takeovers have been done in apparent circumvention of the mandatory bid provisions of the takeover law. Amongst the management buy-outs that have occurred, many experts felt that "share parking" in advance of takeovers had become widespread and the supervising agencies had exhibited little real power to ensure effective disclosure (OECD, 2011a).

The SMA appears to have lacked the capacity and willingness to pursue enforcement action with respect to such takeovers, perhaps reflecting its lack of de facto independence (ranked 73 according to the 2012/13 Global Competitiveness Report). The recent legislative amendments improve operational independence of the SMA by allowing parliament on the government's proposal to appoint and discharge the director and council members and extend their term in office from five to six years. However, it is not clear whether the SMA has the resources and financial independence necessary to carry out its duties, as its supervision fee structure and annual budget plans are subject to government approval, and its employees remain subject to public employment regulations that prevent them from receiving market based salaries. At a practical level, it is worth noting that the authority has only 49 employees spread over eight separate divisions, which would suggest that the depth of its capacity to oversee the market is limited (OECD, 2011a).

The independence of the SMA is further undermined in an environment of state block holders and a substantial number of weak minority shareholders. According to the 2012/13 Global Competitiveness Report, Slovenia ranks 127 in terms of protection of minority shareholders' interests. Although the Slovenian legislation is broadly comparable to other OECD countries, de facto, the possibility of political interference and limited protection of minority shareholders' interest that are rarely represented in the monitoring boards hinder the development of the stock market. As an example, one should consider Abanka, which requires a capital injection, and its owner Triglav, as both are controlled by the state. From the perspective of private shareholders of Triglav, it might make sense to close Abanka and write-off the losses, because its market value is much smaller than the required recapitalisation. Since both institutions are state-owned, Triglav is going to recapitalise Abanka, irrespective of the interests of private shareholders.

Another important dimension of investor protection is the extent of disclosure about related party transactions. Despite the new legislation regulating the approval of related-party transactions, according to the World Bank Doing Business Indicators, Slovenia has an index of 5 on a scale between 0 and 10. The disclosure of related party transactions is particularly important in countries with small populations, explaining why relatively small countries, such as Estonia, New Zealand and Sweden have opted for very high levels of disclosure.

\section{Preventing future crises}

Although banking regulation and supervision is broadly in line with international standards and the Bank of Slovenia has duly transposed EU banking directives and has incorporated many guidelines from the European Banking Authority, there have been weaknesses in the implementation of these standards (IMF, 2012a). Hence, it is important to strengthen banking regulation and supervision within the framework of the EU banking union. 
ECO/WKP(2013)51

\section{Bank supervision should be more transparent and forward-looking}

The root of the crisis is poor credit management by banks and the supervision by the Bank of Slovenia appears retrospectively as having been insufficient to control banks' credit policies, notably the high concentration of risk in the construction sector and financial holdings. Although the supervisor has been requiring banks to strengthen their credit risk management - and had introduced a macro-prudential instrument (extra capital buffer) during the boom years - it has not been successful enough in obtaining significant improvements (IMF, 2012a).

On the micro-prudential supervision side, the supervisor remains quite optimistic about banks' ability to manage credit risk and resolve NPLs by themselves as the Bank of Slovenia seems keener on solving the issue of bad loans by creating specific units within the banks rather than creating a bad bank. The provisioning in Slovenia is done in accordance with International Accounting Standards, which gives the banks the discretion to apply different provisioning methods that are not always comparable. Given poor risk practices of some banks, such discretion is questionable and banks should be required to apply a homogeneous method of provisioning.

The Bank of Slovenia should develop on-site examinations of loan portfolios on larger samples and induce banks to take a more conservative stance on collateral valuations (IMF, 2012a). Taking into account the difficulty in improving banks' risk practices and corporate governance, the Bank of Slovenia should be even more conservative and proactive in the future in its provisioning requirements and ensure that other remedial actions are taken in a timely manner. Given the small size of the Slovenian economy and tight interlinkages between banks and firms, the Bank of Slovenia should be especially prudent with provisioning requirements for large and related exposures.

The quality of micro-financial regulation may also suffer from the fact that a number of useful indicators are not collected or the frequency of collection is not sufficient. Reporting of problem assets lacks granularity (IMF, 2012a). Although, the supervisor shares its information on NPLs for private firms, households and, entrepreneurs, the data on NPLs for SOEs is not made available. This is a weakness given the dominance of the state in the economy. Despite a very high share of renegotiated loans, the Bank of Slovenia possesses very little information about the nature of these loans (what share is renegotiated after they are overdue, what share becomes overdue in the future, what is the coverage ratio of renegotiated loans). Data collected on related parties is incomplete (IMF, 2012a). As to frequency of data collection, capital adequacy ratios are only collected quarterly, though this is consistent with EU requirements. The survey that allows having reliable information on overdue loans for households is only annual. Although alternative sources of information are available, the share of NPL is not published on the webpage of the Bank of Slovenia.

More importantly, the quality of banking supervision might be undermined by the dominance of state ownership among banks and enterprises. Even though all banks are subject to the same standards of prudential oversight, in practice regulatory forbearance is likely to be more often applied to SOBs because bank supervisors might prove unable or unwilling to require that SOBs adhere to regulations (Andrews, 2010). Last but not least, the effectiveness of the supervision is likely to be undermined by understaffing of the banking supervisor and, hence, it would be advisable to expand off-site and to a lesser degree on-site staff (IMF, 2012a).

The powers of the Bank of Slovenia to ensure that additional capital is raised by SOBs is limited (IMF, 2012a). First, shareholders (which are often the state) have the right not to fulfil the supervisor's requirement to increase capital. Second, until recently the supervisor lacked powers to evaluate, license and directly remove unqualified members of the supervisory board. The law providing such powers has been adopted by the parliament in mid-December 2012 and it remains to be seen how it is implemented in practice. This is crucial as, similar to provisioning requirements, the Bank of Slovenia has to become more conservative and proactive in its capital requirements (and more generally in its supervisory duties) if it wants to avoid a repetition of the current banking crisis. 
While the Bank of Slovenia has an explicit mandate for financial stability, the only macro-prudential instrument that is currently in use is annual micro and macro stress-tests (the previous capital buffer has been scrapped as the financial crisis unfolds). As mentioned earlier, the results of these tests are not publicly disclosed. The publication of the annual Financial Stability Review is commendable, but the Bank of Slovenia has to develop new macro-prudential tools and be more forceful in implementing its own recommendations.

To maintain market discipline, it is important to ensure that unviable banks undergo an orderly resolution. However, the involvement of the Bank of Slovenia in the BAMC appears to be insufficient as it only has a consultative role. New amendments to the Banking Act, passed in mid-December 2012, entrust the Bank of Slovenia with resolution powers, such as the appointment of a bank's extraordinary management board, compulsory disposal of shares of a bank for the account of existing shareholders, the increase in the initial capital and transfer of assets and liabilities of a bank to an acquiring company. The explicit granting of such powers is a welcome step forward. Yet, effectiveness of the law might be limited, because the law does not allow the Bank of Slovenia to implement a bail-in (impose losses on bond holders) and create bridge banks (a temporary bank to administer assets and liabilities of a failed bank). The experience with the BAMC should serve as a learning experience for the use of a bridge bank as a resolution tool in the future. Moreover, the new law does not specify the source of funding arrangements in order to minimise taxpayer's exposure to losses from solvency or liquidity support. Best practices show that such arrangements could be financed by institutions themselves, such as resolution funds already established in Germany and Sweden and funded by levies on banks' assets. Finally, given the likelihood of conflicts of interest, the functional separation of resolution activities from the supervision activities is necessary.

Finally, greater public transparency of the Bank of Slovenia could help reassure financial markets. Currently, the Bank of Slovenia's webpage contains a very limited amount of information on the structure of banks' assets, liabilities, capital, solvency, non-performing loans, liquidity and profitability. The English version of the webpage contains only very aggregated balance sheet data on the banking sector that lacks granularity and does not provide data on profit and loss statements, loan quality or capital adequacy. The Slovenian version provides more information, but it also lacks the degree of granularity necessary for the analysis.

\section{Comprehensive credit registry for enterprises is essential for alleviating information asymmetries between firms and banks}

As mentioned earlier, Slovenian firms borrow simultaneously from multiple banks, but in the absence of credit information sharing between banks, this could have been one of the reasons for poor risk management prior to the crisis. A comprehensive credit registry that covers all borrowing firms and provides positive (loan conditions and its repayment) and negative (non-repayment of loans, loan restructuring) information is an important tool for development of sustainable credit markets for a number of reasons. First, it attenuates problems of adverse selection for banks allowing them to better evaluate risk and disciplines borrowers that know that their credit history is taken into account in banks' decisions. Second, it decreases "hold-up" problems for borrowers who cannot switch banks due to information asymmetries and, thus, are constrained to pay higher interest rates. A well designed credit information sharing scheme has been shown to lower the cost of intermediation and to improve access to credit (Brown et al., 2009). Finally, credit registries help supervisors monitor credit risk of individual financial institutions, as well as analyse the stability of the entire financial system, improve policy design, analyse the impact of financial regulations and conduct research.

The Bank of Slovenia established a credit registry in 1993 for supervisory purposes. The reporting is mandatory for all banks that have to report positive and negative information. However, banks do not have the right to access all information stored in this credit registry. While all essential information is shared for 
existing borrowers, there is no comprehensive access to the credit history of potential borrowers from other banks. The Bank of Slovenia has to be required to share a complete set of information with individual banks to alleviate informational asymmetries between banks and borrowers. The history of the shared information could be limited to five years in order to balance disciplining borrowers and providing them with a second chance. At the same time, borrowers should have the right to verify the correctness of the collected information.

\section{Box 3. Recommendations to restructure banks and smooth deleveraging of the private sector}

\section{Cleaning-up banks' balance sheets}

- Conduct and disclose the main results of new bottom-up ("due-diligence") and top-down stress tests of the banking sector, which should be made under conservative and transparent assumptions.

- $\quad$ Strengthen financial independence of the Bank Asset Management Company (BAMC) by providing it with sufficient capital. The non-executive directors of the management board and members of the interministerial committee should meet the same professional requirements as executive directors.

- $\quad$ Ring-fenced assets should be fully disposed at the end of the mandate of the BAMC and not transferred as currently envisaged to the sovereign holding company to avoid a permanent postponement of the resolution of impaired assets.

- $\quad$ Recapitalise distressed but viable banks, preferably by issuing shares, and wind down non-viable banks. To reduce fiscal costs of bank resolution, holders of subordinated debt and lower-ranked hybrid capital instruments should absorb losses.

- $\quad$ Privatise state-owned banks and do not retain a blocking minority shareholding.

\section{Simplifying insolvency procedures}

- $\quad$ Encourage distressed firms to apply early for insolvency procedures by a better law enforcement concerning the liability of debtors that fail to apply for insolvency procedures in a timely manner, encouraging balancesheet insolvent borrowers to apply, and distinguishing between honest and fraudulent bankruptcy.

- Ease restructuring of distressed businesses via simplified fast track in-court reorganisation of small and medium-sized enterprises and establishment of a legal framework for out-of-court restructuring.

- Enforce the existing legislation that limits duration of certain insolvency procedures. Ultimately, the objective is to end all insolvency procedures within one year.

\section{Preventing future crises via enhanced corporate governance and banking supervision}

- Develop equity markets by eliminating political interference into management of listed companies, improved rights of minority shareholders and enhancing operational and financial independence of the Slovenian Securities Market Authorities.

- $\quad$ Enhance transparency and data disclosure by the Bank of Slovenia and ensure that a complete set of credit information from its credit registry is shared with banks.

- Make banking supervision more conservative and forward-looking by adopting a much more prudent approach to large and related exposures.

- $\quad$ Further improve resolution powers of the Bank of Slovenia by providing it with additional tools (bridge bank and bail-in) and foreseeing a financing arrangement, such as a resolution fund. 


\section{Bibliography}

Andrews, A.M. (2010), "State-Owned Banks, Stability, Privatization, and Growth: Practical Policy Decisions in a World Without Empirical Proof", IMF Working Paper, No. WP/05/10, International Monetary Fund.

Bonin, J.P., I. Hasan and P. Wachtel (2005), "Privatization matters: Bank efficiency in transition countries", Journal of Banking and Finance, Vol. 29, No. 8-9, Elsevier, http://dx.doi.org/10.1016/j.jbankfin.2005.03.012.

Brown, M., T. Jappelli and M. Pagano (2009), "Information Sharing and Credit: Firm-Level Evidence from Transition Countries", Journal of Financial Intermediation, Vol. 18, No. 2, Elsevier, http://dx.doi.org/10.1016/j.jfi.2008.04.002.

Caballero, R.J., T. Hoshi and A.K. Kashyap (2008), "Zombie Lending and Depressed Restructuring in Japan", American Economic Review, Vol.98, No. 5, American Economic Association, http://dx.doi.org/10.1257/aer.98.5.1943.

Dahlström, C., V. Lapuente and J. Teorell (2011), "Dimensions of Bureaucracy II: A Cross- National Dataset on the Structure and Behavior of Public Administration", QoG Working Paper Series, No. 2011:6, The Quality of Government Institute, University of Gothenburg.

Damijan, J. (2012), “What Went Wrong in Slovenia?”, OpEd in Die Presse, 8 September.

EBCI (European Bank Coordination Initiative) (2012), "Non-Performing Loans in Central, Eastern and Southeastern Europe", Report prepared by a Working Group set up in the context of the European Bank Coordination "Vienna" Initiative; World Bank, International Monetary Fund, European Investment Bank, European Bank for Reconstruction and Development, European Central Bank and European Commission.

ECB (2012), "Opinion of the European Central Bank on strengthening bank stability”, 19 September 2012, CON/2012/71, European Central Bank.

Ergungor, O.E. (2007), “On the Resolution of Financial Crises: The Swedish Experience”, Policy Discussion Papers, No. 21, Federal Reserve Bank of Cleveland.

European Commission (2012), "In-Depth Review for Slovenia in Accordance with Article 5 of Regulation (EU) No 1176/2011 on the Prevention and Correction of Macroeconomic Imbalances", Commission Staff Working Document, No. 158.

European Commission (2011a), A Second Chance for Entrepreneurs: Prevention of Bankruptcy, Simplification of Bankruptcy Procedures and Support for a Fresh Start, Final Report of the Expert Group, Directorate-General for Enterprise and Industry.

European Commission (2011b), Business Dynamics: Start-ups, Business Transfers and Bankruptcy, Directorate-General for Enterprise and Industry, European Commission.

Financial Stability Board (2011), "Key Attributes of Effective Resolution Regimes for Financial Institutions", Financial Stability Board, November. 
Hoshi, T. and A.K. Kashyap (2010), "Will the U.S. Bank Recapitalization Succeed? Eight Lessons from Japan”, Journal of Financial Economics, Vol. 97, No. 3, Elsevier, http://dx.doi.org/10.1016/j.jfineco.2010.02.005.

IMF (2012a), "From Bail-out to Bail-in: Mandatory Debt Restructuring of Systemic Financial Institutions", IMF Staff Discussion Note, International Monetary Fund, April.

IMF (2012b), "Republic of Slovenia: Detailed Assessment of Observance of Basel Core Principles for Effective Banking Supervision", IMF Country Report, No. 12/324, International Monetary Fund.

Khwaja, A.I. and A. Mian (2005), "Do Lenders Favor Politically Connected Firms? Rent Provision in an Emerging Financial Market", The Quarterly Journal of Economics, Vol. 120, No. 4, Oxford Journals, http://dx.doi.org/10.1162/003355305775097524.

Klingebiel, D. (2000) "The Use of Asset Management Companies in the Resolution of Banking Crises", World Bank Policy Research Working Papers, No. 2284, World Bank, http://dx.doi.org/10.1596/1813-9450-2284.

Lindstrom, N. and D. Piroska (2007), "The Politics of Privatization and Europeanization in Europe's Periphery: Slovenian Banks and Breweries for Sale?", Competition and Change, Vol. 11, No. 2.

McKinsey (2012), The Triple Transformation. Achieving a Sustainable Business Model, 2nd McKinsey Annual Review on the Banking Industry, McKinsey\&Company.

OECD (2011a), Corporate Governance in Slovenia 2011, OECD Publishing, http://dx.doi.org/10.1787/9789264097704-en.

OECD (2011b), OECD Economic Surveys: Slovenia 2011, OECD Publishing, http://dx.doi.org/10.1787/eco_surveys-svn-2011-en.

Ruscher, E. and G.B. Wolff (2012), "Corporate Balance Sheet Adjustment: Stylised Facts, Causes and Consequences", Bruegel Working Paper, No. 3, Bruegel.

Sapienza, P. (2004), "The Effects of Government Ownership on Bank Lending", Journal of Financial Economics, Vol. 72, No. 2, Elsevier, http://dx.doi.org/10.1016/j.jfineco.2002.10.002.

Tang, G. and C. Upper (2010), "Debt Reduction after Crises”, BIS Quarterly Review, Bank for International Settlements, September.

WEF (2012), Global Competitiveness Report 2012-2013, World Economic Forum. 
ECO/WKP(2013)51

\section{WORKING PAPERS}

The full series of Economics Department Working Papers can be consulted at www.oecd.org/eco/workingpapers/

1058. Assessing the efficiency of welfare spending in Slovenia with data envelopment analysis (June 2013) by Matevz Hribernik and Rafał Kierzenkowski

1057. Policy determinants of school outcomes under model uncertainty: evidence from South Africa (June 2013) by Thomas Laurent, Fabrice Murtin, Geoff Barnard, Dean Janse van Rensburg, Vijay Reddy, George Frempong and Lolita Winnaar

1056. Improving education quality in South Africa (June 2013) by Fabrice Murtin

1055. The 90\% public debt threshold: the rise and fall of a stylised fact (June 2013) by Balázs Égert

1054. Challenges to sustain Poland's growth model

(June 2013) by Balázs Égert and Rafał Kierzenkowski

1053. Reforming agriculture and promoting Japan's integration in the world economy

(May 2013) by Randall S. Jones and Shingo Kimura

1052. Inequality and poverty in the United States: public policies for inclusive growth (May 2013) by Oliver Denk, Robert Hagemann, Patrick Lenain and Valentin Somma

1051. Fiscal federalism and its impact on economic activity, public investment and the performance of educational systems

(May 2013) by Hansjörg Blöchliger, Balázs Égert and Kaja Fredriksen

1050. Restoring Japan's fiscal sustainability

(May 2013) by Randall S. Jones and Satoshi Urasawa

1049. Measuring total factor productivity at the firm level using OECD-ORBIS

(May 2013) by Peter Gal

1048. A projection method for public health and long-term care expenditures

by Christine de la Maisonneuve and Joaquim Oliveira Martins (forthcoming)

1047. R\&D, patenting and growth: the role of public policy

(May 2013) by Ben Westmore

1046. Knowledge-based capital, innovation and resource allocation

(May 2013) by Dan Andrews and Chiara Criscuolo

1045. Reforms for a Cleaner, Healthier Environment in China

(April 2013) by Sam Hill

1044. Making the tax system less distortive in Switzerland

(April 2013) by Andrés Fuentes 
1043. The determinants of informality in Mexico's states

(April 2013) by Sean M. Dougherty and Octavio Escobar

1042. Legal reform, contract enforcement and firm size in Mexico

(April 2013) by Sean M. Dougherty

1041. Improving the economic situation of young people in France

(April 2013) by Hervé Boulhol

Améliorer la situation économique des jeunes en France

(avril 2013) par Hervé Boulhol

1040. Improving employment prospects for young workers in Spain

(April 2013) by Anita Wölfl

1039. Youth labour market performance in Spain and its determinants - a micro-level perspective

(April 2013) by Juan J. Dolado, Marcel Jansen, Florentino Felgueroso, Andres Fuentes and Anita Wölfl

1038. The efficiency and equity of the tax and transfer system in France

(April 2013) by Balázs Égert

Efficacité et équité du système de prélèvements et de transferts en France

(avril 2013) par Balázs Égert

1037. Income inequality and poverty in Colombia. Part 2. The redistributive impact of taxes and transfers

(April 2013) by Isabelle Joumard and Juliana Londoño Vélez

1036. Income inequality and poverty in Colombia. Part 1. The role of the labour market

(April 2013) by Isabelle Joumard and Juliana Londoño Vélez

1035. Policy options to durably resolve euro area imbalances

(March 2013) by Yvan Guillemette and Dave Turner

1034. Labour market, welfare reform and inequality in the United Kingdom

(March 2013) by Christophe André, Clara Garcia, Giulia Giupponi and Jon Kristian Pareliussen

1033. Work incentives and Universal Credit - reform of the benefit system in the United Kingdom (March 2013) by Jon Kristian Pareliussen

1032. Strengthening social cohesion in Luxembourg: making efficiency and equity go hand in hand

(March 2013) by Jean-Marc Fournier and Clara Garcia

1031. The price of oil - Will it start rising again?

(March 2013) by Jean-Marc Fournier, Isabell Koske, Isabelle Wanner and Vera Zipperer

1030. The system of revenue sharing and fiscal transfers in China

(February 2013) by Xiao Wang and Richard Herd

1029. The declining competitiveness of French firms reflects a generalised supply-side problem (February 2013) by Hervé Boulhol and Patrizio Sicari 